\title{
Common Genetic Etiologies and Biological Pathways Shared Between Autism Spectrum Disorders and Intellectual Disabilities
}

\author{
Liana Kaufman ${ }^{1}$, Abdul Noor ${ }^{1}$, Muhammad Ayub2,3 and John B. Vincent ${ }^{1,4}$ \\ ${ }^{1}$ Neurogenetics Section, The Centre for Addiction \& Mental Health, Toronto, Ontario \\ 2Tees, Esk and Wear Valleys NHS Foundation Trust \\ ${ }^{3}$ School for Medicine and Health, University of Durham \\ Wolfson Research Institute Queen's Campus, Stockton on Tees \\ ${ }^{4}$ Department of Psychiatry, University of Toronto, Toronto, Ontario \\ 1,4Canada \\ 2,3United Kingdom
}

\section{Introduction}

\subsection{Definitions of ID and autism}

Intellectual disability (ID) is a common neurodevelopmental disorder that is characterized by an intelligence quotient (IQ) lower than 70, and deficits in at least two behaviors related to adaptive functioning diagnosed by 18 years of age (American Psychiatric Association, 2000). Adaptive functioning behaviours can be defined as the ability to acquire skills that help an individual to live independently and to cope with everyday life, and involves skills such as language/communication, social skills, home living and safety. ID ranges in its severity and may either be present co-morbidly with many congenital syndromes, or may present alone.

Autism is a severe, lifelong neurodevelopmental disorder characterized by impairments in three major domains: communication, socialization, and repetitive behavior. Leo Kanner first described this developmental disorder in 1943 as a social disorder featuring the innate inability to form typical, affective contact with others (Kanner, 1943). It is now known that the Autism Spectrum Disorder (ASD) includes a widely variable range of clinical phenotypes that have been grouped into individual disorders. Autistic disorder (autism), Asperger syndrome, pervasive developmental disorder not otherwise specified (PDD-NOS), Rett syndrome and child disintegrative disorder (CDD) are all currently separate diagnoses in the DSM-IV under the umbrella title "Pervasive Developmental Disorders"(American Psychiatric Association, 2000). These disorders differ from each other with regard to severity of symptoms, early development of language, deterioration in skills once they have developed, and cognitive development.

Individuals with autism show severe deficits in all three major phenotypic domains and present with abnormal development before age 3 years. In addition, cognitive functioning is frequently delayed. Individuals with Broad Autism Phenotype (BAP) have some symptoms of autism, but do not meet the full criteria for autism or ASD (Hurley et al., 2007). BAP is 
currently not a recognized diagnosis within the DSM-IV, however, it can be useful when looking at familiality in ASDs.

Asperger syndrome is characterized by qualitative impairment in social interaction and restricted repetitive and stereotyped patterns of behavior, interests and activities. Language and cognitive development is relatively unaffected in these individuals, however pragmatic or social language is often delayed (McConachie \& Diggle, 2007). Individuals with PDDNOS meet autism criteria and have later age of onset. These individuals may also show severe and pervasive impairment in one or two of the three core domains with or without cognitive or language delay. Rett syndrome occurs almost exclusively occurs in females and it is characterized by developmental arrest between 6 and 18 months of age, followed by loss of speech, stereotypical movements, microcephaly, seizures, and intellectual disability (Hagberg et al., 1983). CDD is characterized by normal development for at least the first two years (but up to 10 years) of life, followed by clinically significant loss of acquired skills. Individuals with CDD must not meet the diagnostic criteria for Rett syndrome or schizophrenia. They also must display at least two of the three diagnostic domains for autism.

While ASDs are often associated with ID, it should be noted that not all individuals with ASD have cognitive deficits. The current DSM-IV statistic states that $75 \%$ of individuals with ASD have some degree of intellectual disability. However, this may be an outdated overestimate. More recent studies suggest an increasingly modest level; approximately $50-60 \%$ [71\%(Chakrabarti \& Fombonne, 2001) 63\%(Bertrand et al., 2001); 40\%(Baird et al., 2006), $50 \%$ (Charman et al., 2011]. With increased awareness in the general population and a greater understanding of the problem by professionals, an increasing number of people with high functioning Autism and Asperger syndrome are diagnosed with the condition. This has probably changed the proportion of cases with identifiable ID among the ASD population. It is also possible that expanding the diagnostic criteria for ASDs, which historically were much more limited, might explain this decrease (Charman et al., 2011).

The new DSM-V, which will be available in 2013, will define ASDs differently than the current version. The three behavioural domains will be condensed into two: Social communication and repetitive behaviours/narrow interests. In addition, the separate diagnoses within the spectrum will be removed. Autism, Rett syndrome, Asperger syndrome, PDD-NOS and CDD will all be classified as "autism spectrum disorder" with a specified etiology/syndrome if known (e.g. ASD with Rett syndrome; DSM-5 Proposed Revisions, 2010). In addition, a level of severity will be assigned to each diagnosis, which will reflect the functional level of the individual. The alteration in nomenclature reflects the clinical and interventional needs of the individuals and is intended to be more reflective of what is known of the pathology of the disorder (DSM-5 Proposed Revisions, 2010).

\subsection{Classification of ID by IQ and syndromic vs. nonsyndromic}

ID is currently subdivided into 5 categories based on intelligence quotient (IQ): mild, moderate, severe, profound and unable to classify (American Psychiatric Association, 2000; Table 1). However, epidemiological studies often use a simplified classification, grouping their subjects into mild ID (IQ50-70) and severe ID (IQ<50; Ropers \& Hamel, 2005). IQ tests are a set of tasks which are administered to representative population samples for creation of norms. An IQ two standard deviations below the mean or lower is indicative of ID. The distribution of IQ in the population is normal in the main, apart from an increased number 
of cases in the tail on the lower end of IQ. On that basis, the population prevalence of ID should be close to $3 \%$ at least. The studies looking at prevalence of ID were recently reviewed systematically. The range reported varied between 0.93 per 1000 and 156.03 per 1000 (Maulik et al., 2011). Differences in rates of mild ID mainly account for this variation. The reasons are differences in definition of ID criteria, characteristics and setting of the sample studied and differences in methodology. The prevalence of severe ID is relatively stable (3-4 per 1000; (Roeleveld et al., 1997; Leonard \& Wen, 2002; Emerson, 2007).

\begin{tabular}{||c|c|c|c||}
\hline Severity & IQ & Proportion of ID & Functional Level \\
\hline Borderline & $70-84$ & N/A & $\begin{array}{c}\text { Can live independently; May require } \\
\text { low level support }\end{array}$ \\
\hline Mild & $50-69$ & $85 \%$ & $\begin{array}{c}\text { Can often live independently with } \\
\text { social support }\end{array}$ \\
\hline Moderate & $35-49$ & $10 \%$ & $\begin{array}{c}\text { Acquire some communication and self- } \\
\text { help skills, require moderate } \\
\text { supervision }\end{array}$ \\
\hline Severe & $20-34$ & $3-4 \%$ & $\begin{array}{c}\text { Acquire only basic self-help and } \\
\text { communication skills, require } \\
\text { supervision }\end{array}$ \\
\hline $\begin{array}{c}\text { Profound/ } \\
\text { Unspecified }\end{array}$ & $<20$ & $1-2 \%$ & $\begin{array}{c}\text { Require highly structured and } \\
\text { supervised living conditions }\end{array}$ \\
\hline
\end{tabular}

Table 1. This table indicates the categories of intellectual disabilities by IQ and ability to function in society as indicated by the DSM-IV-TR.

The new DSM-5 will likely be changing the severity criteria to encompass functional behavioural deficits and the level of interference that these have in the lives of affected individuals (DSM-5 Proposed Revisions, 2010). Although the new criteria have not yet been established, it will likely echo the changes to the criteria for autism, focusing on functional level as opposed to strict IQ cut-offs. The manual will also be changing the wording of the ID diagnostic criteria to encourage cultural sensitivity and relevance, and to ensure that culturally validated psychometric tests are used to evaluate IQ and level of functioning. In addition to categorization by severity/IQ level, ID can also be grouped into syndromic intellectual disability (S-ID) and non-syndromic intellectual disability (NS-ID). In S-ID, individuals present with an identifiable constellation of clinical features or co-morbidities in addition to ID. While S-ID has a clear definition, there is debate over the classification of NSID. Traditionally, NS-ID has been defined by the presence of intellectual disability as the sole clinical feature. However, it has been a challenge to rule out the presence of more subtle physical signs, neurological anomalies and psychiatric disorders in these individuals, as they may be less apparent, or difficult to diagnose due to the cognitive impairment. Additionally, the symptoms of some syndromes may be so subtle that they are extremely difficult to diagnose unless the features are looked for specifically in the context of a known genetic defect previously associated with these features (Ropers, 2006). Thus the distinction between S-ID and NS-ID is often blurred. 


\subsection{Endophenotypes and "essential autism" versus "complex autism"}

The extreme phenotypic heterogeneity of ASD poses a challenge for the study of underlying etiologies. It has been argued that delineation of the clinical heterogeneity of ASD may help in the identification of more homogeneous sub-groups for the study of etiological factors, and to predict the outcome and treatment choices. While ASD has three core phenotypic domains, it can also be sub-grouped on the basis of presence or absence of certain clinical features, termed endophenotypes. Endophenotypes of ASDs include IQ level, seizures, brain malformations, dysmorphology and head circumference (Viding \& Blakemore, 2007). Historically, based on non-verbal IQ testing, $\sim 70 \%$ of autistic children were reported as having some form of ID (Fombonne, 2003). While it is now thought that this number may be lower, it is essential to look at IQ as an endophenotype of autism when predicting outcomes. Previously published longitudinal studies report that IQ scores can strongly predict longterm outcomes of ASD and are directly associated with the psychopathology of autism, even in young children (Howlin et al., 2004). In addition, preschool cognitive functioning has been found to be a strong predictor of school-age functioning, and high IQ has been shown to be necessary but not sufficient for optimal outcome in the presence of severe language impairment (Stevens et al., 2000).

Another common central nervous system (CNS) dysfunction associated with autism is the high risk of epilepsy (Spence \& Schneider, 2009). The prevalence of seizures in autism is estimated to be up to $46 \%$ (Hughes \& Melyn, 2005) and it has been estimated that as many as $32 \%$ of individuals with epilepsy may meet the diagnostic criteria for ASD (Clarke et al., 2005). Notably, the prevalence of seizures is higher among autistic individuals with moderate to severe ID and individuals with overt motor abnormalities (Tuchman \& Rapin, 2002). Furthermore, individuals with autism plus epilepsy on average have lower IQs. Epilepsy is one of the negative factors contributing to cognitive, adaptive and behavioral/emotional outcomes for autistic individuals (Hara, 2007).

Structural brain malformations, including accentuated Virchow-Robin space, acrocallosal syndrome and polymicrogyria have been reported to be associated with autism (Steiner et al., 2004; Schifter et al., 1994; Zeegers et al., 2006), however, until recently, MRIs have been considered to be of indeterminate value and they are not included in the standard clinical evaluation of autism. A recent study has revealed an unexpectedly high prevalence of brain abnormalities (48\%) in autism patients. Some common abnormalities include white-matter signal abnormalities, severely dilated Virchow-Robin space and temporal lobe structural abnormalities (Boddaert et al., 2009).

Generalized dysmorphology, an indicator of insult in early development, has been reported in $15 \%$ to $20 \%$ of individuals with autism (Miles \& Hillman, 2000) and has been proposed to be a predictor of a poor response to early intensive behavioral intervention. According to the Autism Dysmorphology Measure (ADM) guidelines, the 12 body areas assessed for dysmorphology are: height, hair growth pattern, structure and size of ear, nose size and shape, face size and structure, philtrum, mouth and lips, teeth, hand size, fingers and thumbs, nails and feet. The ADM was developed by the Miles laboratory at the University of Missouri to aid clinicians who are not extensively trained in medical genetics to distinguish between individuals with ASD with and without dysmorphisms (Miles \& Hillman, 2000). Besides generalized dysmorphology, head size abnormalities (microcephaly and macrocephaly) have also been found in autistic individuals. Microcephaly, head circumference $<2$ nd centile, occurs in 5 to $15 \%$ of children with autism and is a predictor of poor outcome (Miles et al., 2005). On the other hand, macrocephaly, head circumference 
$>97_{\text {th }}$ centile has been observed in $\sim 30 \%$ of children with autism (Miles et al., 2000). Generalized dysmorphology and microcephaly have been proposed as good predictors of clinical outcome and may be used to classify the autism phenotype into subgroups: complex autism and essential autism. Complex autism consists of autistic individuals who show evidence of some abnormality in early morphogenesis, manifested by either significant dysmorphology or microcephaly. The remainder without dysmorphic features or microcephaly are classified as having essential autism (Miles et al., 2005), and make up 70$80 \%$ of the autism population.

\subsection{Diagnostic approaches}

The symptoms of most ASDs are usually present by the age of three and may persist throughout the lifespan; however, CDD and PDD-NOS may present later. A number of checklists and diagnostic tools are available for diagnosis of autism. The Childhood Autism Rating Scale (CARS; Schopler et al., 1980) is a commonly used diagnostic checklist which consists of 15 questions scored by the parents and the examiner. It is a reliable and efficient tool that is commonly used in clinics. Another autism screening tool widely used in clinical settings is the Checklist for Autism in Toddlers-modified (M-CHAT). This checklist consists of 23 yes/no questions and is a promising tool for the early diagnosis of autism (Robins et al., 2001). Other such checklists include the Autism Behaviour Checklist (ABC; Witwer \& Lecavalier, 2007) and Gilliam Autism Rating Scale (GARS; South et al., 2002).

The Autism Diagnostic Observation Schedule (ADOS) and Autism Diagnostic InterviewRevised (ADI-R) are two widely accepted instruments used for diagnosis of ASD in both clinical and research settings. ADI-R, a revised version of Autism Diagnostic Interview (ADI), is a semi-structured, investigator-based interview for the caregivers of children with autism and adults for whom autism or ASD is a possible diagnosis (Lord et al., 1994). The ADOS is a semi-structured, standardized assessment of social interactions, communication, play, and imaginative use of objects for children suspected of having ASD (Lord et al., 2000). It is an observational assessment of the child's behaviour, often performed by a psychologist or another trained professional. Checklist tools are widely used in clinical practice because of their ease and efficiency; however, ADI-R and ADOS have been adapted, particularly in recent years, to make them more appropriate for use in clinical settings, as well as for diagnosis of toddlers and patients with intellectual disabilities. In particular, the shorter version of ADOS is becoming increasingly popular in clinics.

All of these diagnostic tools have their own advantages and disadvantages. For example, ADI-R and ADOS are lengthy, require elaborate training and are suitable for use in more specialized settings. The Checklist for Autism in Toddlers-modified (M-CHAT), described earlier in this section, has been particularly useful in the frontline clinical world, as well as for early diagnosis of autism (Robins et al., 2001), and has overcome some of the challenges faced by ADI-R and ADOS. M-CHAT includes a checklist of 23 items to be filled out by parents and it can be administered at a much earlier stage to identify toddlers who are at risk of autism. A recent study has confirmed the validity of this instrument in detecting possible ASD at 16-30 months of age (Kleinman et al., 2008). However, the high sensitivity of this checklist means that some children without autism will fail the screening. It has been suggested that children who fail and do not have autism are at increased risk for other developmental disorders or delays and should be monitored accordingly (Robins et al., 2001). 
Over last two decades the diagnosis of syndromes based on behavioural symptoms has become relatively standardized, although there are some issues around the potential for over diagnosis of higher functioning autism and Asperger syndrome. However, the etiology of ASDs is largely unknown, and few genetic tests or biomarkers have been found to confirm an autism diagnosis. In other words, no laboratory-based means of testing for autism is yet widely available. While various genes have been identified that cause autism, none of them are common, and justification for performing individual testing is debatable. However, tests are currently being offered commercially for a number of these known genes, including CNTNAP2, PTEN and SHANK3 . Recently, microarray technology has also been proposed as a potential diagnostic tool, or a method to determine etiology. Because of the growing number of genes known to cause ASDs, an autism microarray, containing only verified autism causing genes, could be custom made to assess if these genes are aberrant in affected individuals. The proportion of cases with known etiology at this stage will be very small (less than 5\%) and a negative test would not mean an exclusion of the diagnosis. Knowing the root cause of autism may not lead to an alteration in treatment or intervention at this stage, but may be useful for family planning and genetic counseling, as well as for the emotional well being of concerned family members. Additionally, with further phenotype profiling and analysis of individuals with particular mutations, it may be possible to tailor interventions based on genetic diagnoses in the future.

\section{Causes of ID}

ID can be caused by environmental and/or genetic factors. However, for up to $60 \%$ of cases, there is no identifiable cause (Rauch et al., 2006). Environmental exposure to certain teratogens, viruses or radiation can cause ID, as can severe head trauma or injury causing lack of oxygen to the brain (Chelly et al., 2006). While these factors explain some cases of ID, it is also important to consider genetic etiology.

Genetic causes of ID are thought to be present in $25-50 \%$ of cases, although this number increases proportionally with severity (McLaren \& Bryson, 1987). Chromosomal abnormalities have been reported in ID, with a broad range of prevalence, and many different types of aberrations have been identified (Rauch et al., 2006). Over the past 15 years many single gene causes of ID have been identified as well. Many of these genes cause a broad range of phenotypes including syndromic ID (S-ID), non-syndromic ID (NS-ID), autism and other neurodevelopmental and psychiatric phenotypes. This suggests that it is likely that other genetic modifiers or environmental factors may be involved in disease etiology, and that similar biological pathways, when disturbed, have the potential to lead to a range of these conditions. This illustrates the need for detailed study and descriptions of phenotypes for each gene and mutation. Most of the mutations that cause ID are highly penetrant and are inherited in a Mendelian fashion. Many known ID genes are on the Xchromosome, however the number of autosomal genes associated with ID is growing rapidly (Kaufman et al., 2010). This is due to advances in technology which allow us to study the autosomes more efficiently, along with a shift in focus from the X-chromosome to the autosomes resulting from the realization that the X-linked genes may only account for $\sim 10 \%$ of ID cases, while autosomal genes may account for many more (Ropers \& Hamel, 2005). 


\section{Causes of autism}

\subsection{Genetic contributions}

The causes of autism are likely far more complex than the causes of ID. Genetic factors clearly play a prominent role. The evidence for the involvement of genetic factors in the etiology of autism comes primarily from family and twin studies and is further supported by cytogenetic and molecular studies. Several sibling concordance studies have provided a strong indication that autism has a significant genetic component. Studies over the years, including analyses of autism probands with severe ID, evaluations of the developmental, social, and psychiatric histories of siblings of autistic individuals and reviews of familial aggregation in large autism cohorts, have all displayed higher than expected familiality (Baird \& August, 1985; Piven et al., 1990; Bolton et al., 1994). A recent study examined the cognitive, adaptive, social, imitation, play, and language abilities of 42 non-autistic siblings (of autism probands) and 20 toddlers with no family history of autism. The siblings were below average in expressive language abilities and IQ. They had lower mean receptive language, adaptive behavior, and social communication skills. They used fewer words, distal gestures, and social smiles than children with no familial history of autism (Toth et al., 2007).

On the other hand, the familiality of autism does not imply that genetic factors are exclusively responsible for the disease, and role of the environmental factors, which are also shared by family members who live together, cannot be excluded by these studies alone. Twin studies provide an alternative approach for investigating the relative magnitude of genetic and/or environmental factors on the autism phenotype and penetrance. In 1977, a landmark study by Folstein and Rutter demonstrated a significant difference between monozygotic (MZ) and dizygotic (DZ) twins in their concordance for autism (Folstein \& Rutter, 1977). This difference in concordance suggested a major role for genes in the etiology of autism and this was confirmed by subsequent studies (Ritvo et al., 1985; Steffenburg et al., 1989). Most recently, a large scale study of 277 twin pairs (210 DZ and $67 \mathrm{MZ}$ ) reported $88 \%$ concordance of autism for MZ twins and $31 \%$ concordance of autism for DZ twins. In MZ twins, the authors also observed a higher prevalence of bipolar disorder and Asperger syndrome with a higher concordance of the latter (Rosenberg et al., 2009). The finding of increased bipolar disorder in twins is interesting because the co-morbidity of psychiatric disorders (eg. anxiety disorder, ADHD, etc) in children with autism is up to $70 \%$ (Charman et al., 2011), and suggests significant overlap in genetic etiology between different psychiatric disorders. Specific genetic causes for autism will be outlined more thoroughly later in this chapter.

\subsection{Epigenetic contributions}

It is widely accepted that genetic factors play a major role in the etiology of ASD, however, epigenetic factors may also be an important determinant of the autism phenotype. Epigenetic modifications include cytosine methylation and post-translational modification of histone proteins, and act as a mechanism to control gene expression (Samaco et al., 2005). The epigenetic regulation of gene expression can be influenced by exposure to environmental factors and can show parent of origin effects. Notably, epigenetic factors play a central role in pathogenesis of two single gene disorders, Rett syndrome and Fragile $X$ syndrome (FXS), that are commonly associated with autism (Brown et al., 1982; Gillberg, 1986). Rett syndrome, a progressive neurodevelopmental disorder, is classified among 
ASDs. It is caused by mutation in the MECP2 gene that encodes the methyl-CpG-binding protein 2, which is involved in epigenetic regulation of gene expression (Amir et al., 1999). JARID1C, a relatively common ID gene associated with some cases of autism (Adegbola et al., 2008) has been shown to regulate the methylation of histones and function in epigenetic transcriptional repression (Tahiliani et al., 2007).

In addition, some autism (and ID) genes are regulated by known epigenetic mechanisms. FXS is caused by the expansion of a tract of CGG repeats in the $5^{\prime}$ untranslated region of the FMR1 gene. This expansion results in epigenetic silencing of the region, causing loss of expression of the gene, thus, FXS is caused by a genetic mutation resulting in epigenetic dysregulation (Hagerman et al., 2005). The RELN gene is another interesting example of possible contributions of epigenetic factors to ASD. The RELN gene encodes a large extracellular matrix protein that organizes neuronal positioning during corticogenesis and is regulated by epigenetic mechanisms. Several independent studies have shown an association between RELN and ASD (Skaar et al., 2005; Ashley-Koch et al., 2007; Holt et al., 2010). Interestingly, reduced levels of reelin and its isoforms have been previously shown in autistic twins and their first degree relatives (Fatemi et al., 2005).

Genomic imprinting is another mode of regulation of gene expression by epigenetic modifications and it results in parent of origin-specific gene expression. Genomic duplications of an imprinted region on the proximal long arm of chromosome 15 (15q11q13) are associated with $0.5-3.0 \%$ of autism cases (Hogart et al., 2010).

\subsection{Other factors}

Support for possible environmental factors contributing to the causation of autism comes from the incomplete concordance in monozygotic twins. Additionally, at this point in time, known genetic defects only explain a small proportion of autism patients. Furthermore, there is evidence that in utero exposure to valproic acid and thalidomide may increase the risk of ASD (Arndt et al., 2005). One long-term study of 632 children exposed to antiepileptic drugs during gestation, found that $6.3 \%$ of the children exposed to valproic acid in utero had ASD or some features of ASD. This incidence is seven times higher than the control group (0.9\%; (Bromley et al., 2008)). Similarly, a higher incidence of autism has been reported among children prenatally exposed to thalidomide. In a population of 100 Swedish thalidomide embryopathy cases, at least four met full diagnostic criteria for autism (Stromland et al., 1994). Animal models have also demonstrated that early serotonergic neural development is disrupted in rats exposed to thalidomide or valproic acid on the ninth day of gestation, conferring increased risk for the development of ASD-related behaviours (Narita et al., 2010).

Mercury $(\mathrm{Hg})$, because of its known neurotoxicity, has drawn particular attention in relation to the neurodevelopment of individuals with autism, and a number of studies have compared the level of $\mathrm{Hg}$ in blood, hair, or urine in children with autism versus without autism. However, none of these studies have shown any substantial evidence of involvement of $\mathrm{Hg}$ in autism. Recently, a study conducted on 452 autism patients failed to demonstrate any difference in blood $\mathrm{Hg}$ level of autism patients compared to controls (Hertz-Picciotto et al., 2010).

Childhood immunization is an environmental factor that has been popularized in the media as a potential cause of autism. The use of mercury in vaccines has been one of the prime sources of concern surrounding vaccines and their role in autism (Baker, 2008). However, 
there is no consistent evidence in support of the theory that vaccines are related to the etiology of autism. In the late 1990s, a link between vaccines and autism was reported by clinical observation of the onset of autism soon after vaccination of children (Wakefield et al., 1998). These observations triggered a series of studies in the US, UK, Europe and Japan, however, none of these studies found any compelling evidence for a link between vaccines and autism. The original study has since been retracted (Murch et al., 2004; Anonymous, 2010)

Although the majority of research to date has focused on genetic factors involved in the etiology of autism, non-genetic factors are also likely to contribute. Our knowledge of these factors is, however, currently very limited. It has been suggested that distinct genetic features/pathways may cause distinct domains of autistic behaviour, but this has yet to be tested at the molecular level (Happe \& Ronald, 2008). It does, however, resonate with the idea that autism is a genetically heterogeneous spectrum, and that multiple genetic aberrations may be necessary to reach the autism phenotype threshold (Cook \& Scherer, 2008). The threshold theory postulates that the cumulative effect of several genetic aberrations, for instance a copy number variant together with one or more single nucleotide variants, and possibly in combination with environmental factors, in a single individual, may result in an autism phenotype. These genetic aberrations may include chromosomal, single nucleotide or epigenetic abnormalities. It has also been noted that some genetic aberrations are more penetrant than others and may be more likely to result in a phenotype. In contrast with ID genetics, which are relatively straightforward, autism presents us with a convoluted, likely multigenic/multifactorial disorder for which it may be more difficult to delineate causes.

\section{Epidemiology}

\subsection{Autism \& autism spectrum disorders}

In published literature the incidence of autism is variable, and a worldwide trend of increase in prevalence of autism has been reported. During the 1980s, autism was thought to be rare, with a prevalence of less than 5 per 10,000 persons (Gillberg et al., 1991) and was not categorized as major public health problem. During the 1990s, the prevalence of autism was estimated to be 21 to 31 per 10,000 in preschool children (Fombonne, 1999). A recent review of epidemiologic studies reported a prevalence of 20 per 10,000 for classic autism and 60-70 per 10,000 (1 in 150) for all ASDs (Fombonne, 2009). In addition it reported a prevalence of 30-40 per 10,000 for PDD-NOS and 2 per 10,000 for CDD (Fombonne, 2009). Epidemiologic studies of Asperger syndrome have been more rare, and although current numbers estimate a prevalence of 6 per 10,000, there are severe limitations to calculating this prevalence accurately (Fombonne, 2009). Other recent large scale epidemiological studies have shown that as many as 1 in 100, or 1\% of school age children have an ASD (Baird et al., 2006; BaronCohen et al., 2009; Kogan et al., 2009). It is noteworthy that some of these studies are based on parents' reporting of ASD and it could be argued that these estimates might be falsely high (Kogan et al., 2009). On the other hand, it has been argued that the increasing incidence of autism might be due to increased awareness of public and professionals coupled with the broadening of the diagnostic criteria (Fombonne et al., 2006). Today, the prevalence of ASDs is believed to be very high and this condition is now thought to be second only to Intellectual Disability (ID) among the most common developmental disabilities in the United States (Yeargin-Allsopp et al., 2003). 
It is also noteworthy that there is a gender bias in autism. Among children with autism, the ratio of affected males to females is estimated to be 4:1 (Volkmar et al., 1993) and the male to female ratio for Asperger syndrome is even higher. In contrast, Rett syndrome occurs almost exclusively in females.

\subsection{Intellectual disabilities}

ID is the most common neurodevelopmental disorder in the United States (Yeargin-Allsopp, et al., 2003). The prevalence of ID is between 1 and 3\% (Roeleveld et al., 1997; Leonard \& Wen, 2002) and is present in every social class and culture (Leonard \& Wen, 2002). Despite its universal occurrence, there tends to be higher prevalence of ID in areas of lower socioeconomic status and developing countries, particularly for mild cases (Drews et al., 1995; Roeleveld et al., 1997; Durkin et al., 1998; Durkin, 2002; Emerson, 2007). The variability of prevalence is more pronounced for mild ID than for severe forms. It has been suggested that this discrepancy is likely due to environmental factors (Roeleveld et al., 1997; Durkin et al., 1998; Emerson, 2007).

Approximately 30\% more males are diagnosed with ID than females (McLaren \& Bryson, 1987; American Psychiatric Association, 2000). However, despite a higher ratio of males to females among milder cases of ID, the ratio decreases as IQ decreases (McLaren \& Bryson, 1987; American Psychiatric Association, 2000). Some studies suggest that severe ID may be more prevalent among females (Katusic et al., 1996; Bradley et al., 2002), however these studies were performed in quite specific geographic locations and populations, and may not necessarily be generalizable to other regions. Some of this gender bias can be accounted for by mutations on the X-chromosome. In most cases of X-linked ID (ie. X-linked mental retardation; XLMR) or X-linked autism, more males are affected due to hemizygosity. However, in some disorders, such as Rett syndrome, this ratio is reversed because mutations in the Rett syndrome gene, $M E C P 2$, are generally lethal in haploid genomes. In addition, a rare phenomenon is apparent in female-restricted epilepsy and mental retardation (EFMR), in which heterozygous mutations in the gene PCDH19 cause the disease in females and in which there is reprieve-in-males with hemizygous PCDH19 mutations, who remain unaffected (Dibbens et al., 2008; Hynes et al., 2009). A possible explanation for this reprievein-males phenomenon could be that carrier males have a homogenous population of mutant PCDH19-containing cells, whereas affected females would possess a mosaic population of mutant and wild-type PCDH19-containing cells. It is postulated that this mosaicism, rather than the effect of the mutated protein alone, may disrupt cell-cell communication, resulting in the clinical presentation (Dibbens et al., 2008).

\subsection{Co-morbidity of autism spectrum disorders \& intellectual disability (syndromic and non-syndromic)}

It is often necessary to look at ASDs and ID together, as there is significant overlap between them both in terms of phenotype and in genetic causation. As previously noted, ID is present in $\sim 50-60 \%$ of individuals with autism. Additionally, in a study performed on an ID population, $28 \%$ met the criteria for an autism diagnosis on the ADI-R scale and only half of these cases had been previously diagnosed (Bryson et al., 2008). Similar studies have also shown that within ID populations, the prevalence of autism is $8-20 \%$, and that it is more likely for individuals with severe ID to meet criteria for ASD (Wing \& Gould, 1979; Deb \& 
Prasad, 1994; Nordin \& Gillberg, 1996; Stromme \& Diseth, 2000; de Bildt et al., 2005; Bryson et al., 2008).

ID and autism have multiple overlapping phenotypic domains. The three major phenotypic domains that characterize autism-language deficits, social deficits and stereotypies/ repetitive behaviours-can often be seen to varying degrees in individuals with ID. Individuals with ID often display stereotypies, which tend to become more pronounced and often self-injurious with decreasing IQ (Symons et al., 2005). Studies have found that 30-60\% of individuals with ID display some form of stereotypy (Bodfish et al., 1995; Bodfish et al., 2000; Goldman et al., 2009). Language deficits are often particularly pronounced in individuals with severe and profound ID.

Many ID syndromes have an occurrence of autism that is significantly higher than the occurrence for the general population. For example, a current review of the literature indicates that up to $25-47 \%$ of individuals with Fragile $X$ syndrome, $5-10 \%$ of individuals with Down syndrome, and $16-48 \%$ of individuals with tuberous sclerosis (TSC) also have an autism/PDD diagnosis, compared to $0.6-1 \%$ in the general population (Fombonne, 2009; Molloy et al., 2009). Other ID syndromes that have high occurrence of concordant autism include Angelman syndrome, Joubert Syndrome and Cohen syndrome.

\section{Shared genetics of autism and ID}

\subsection{Shared genetic causes of autism and ID: Syndromic}

As previously noted, there is evidence that several syndromic forms of ID are more likely to present with autism than would be expected in the general population. The observation of overlap in phenotype between autism and the most common XLMR disorder, fragile $X$ mental retardation syndrome (FXS) is a long-standing, albeit controversial one. The frequency of molecular diagnosis of FXS among autistic patients has been reported as high as $12.4 \%$ and as low as $0 \%$, averaging at $7.25 \%$ (Smalley et al., 1988; Gurling et al., 1997). More recent studies indicate a more conservative rate of FXS of 2-4\% (Wassink et al., 2001). Two studies of young FXS individuals demonstrated that $25 \%$ and $33 \%$ met criteria for autism and a review suggests that as many as $47 \%$ may have an ASD (Bailey et al., 1998; Rogers et al., 2001; Molloy et al., 2009); however, it has also been argued that autistic features are not more common among individuals with FXS than among other individuals with ID (Bardoni et al., 2000). Mutations in MECP2 have also been found among individuals with autism (Kim \& Cook, 2000; Orrico et al., 2000; Beyer et al., 2002; Hammer et al., 2002). Autistic features are also frequently present in other ID syndromes such as Down syndrome and phenylketonuria (PKU).

These disorders are rarely mistaken for autism, as other syndromic features assist with the correct diagnostic assignment. On the other hand, there is evidence that even for these wellcharacterized syndromic forms of XLMR, there is a very broad phenotypic expression of the disease. For instance, mutations within the aristaless gene, $A R X$, are responsible for several distinct forms of XLMR and neurological phenotypes: West syndrome (infantile spasms with hypsarrhythmia; Stromme et al. 2002a), Partington syndrome (XLMR with dystonic hand movements; Stromme et al. 2002b), XLAG (Kitamura et al. 2002), XLMR (Bienvenu et al. 2002), Proud syndrome (Kato et al. 2004), and various forms of epilepsy (Stromme et al. 2002a, b; Scheffer et al. 2002). A 24 base pair duplication in ARX has been found in families with West syndrome and Partington syndrome, and recently in several families previously identified as having non-syndromic XLMR. In these families several individuals were 
reported as having only mild intellectual impairment along with autism or autistic-like behaviours (Turner et al., 2002).

\subsection{Shared genetic causes of autism and ID: Non-syndromic}

The Neuroligin 4 (NLGN4) gene has been linked to autism by several studies (Jamain et al., 2003; Laumonnier et al., 2004; Marshall et al., 2008). However, in 2004, Laumonnier et al. identified a family containing individuals with NS-ID, with or without ASD, segregating with a NLGN4 mutation (Laumonnier et al., 2004). This study was the first to suggest that NS-ID and autism may have overlapping genetic etiologies. A similar finding was noted with NRXN1, which interacts with NLGN4. Heterozygous copy number variants (CNV) in this gene have been found in autism while homozygous mutations of NRXN1 cause the S-ID disorder Pitt-Hopkins-like syndrome-2 (PTHSL2; Zweier et al., 2009).

More recently, a truncating mutation was found in SHANK3 in an individual with NS-ID (Hamdan et al., 2011). SHANK3 has been found to cause autism in several studies (Durand et al., 2007; Marshall et al., 2008). In addition, SHANK2 CNVs and sequencing mutations have been found in several cases of both autism and NS-ID, displaying a significant level of etiological overlap between the two disorders (Berkel et al., 2010; Pinto et al., 2010). CNVs, or structural variation within the genome, appear to contribute significantly to the etiology of ID and autism.

PTCHD1 is another X-linked gene that has been implicated in autism and NS-ID. A CNV which deletes PTCHD1 entirely causes NS-ID in one family (Noor et al., 2010). Another $\mathrm{CNV}$, which results in a loss of the first exon and upstream region of PTCHD1, results in autism in another family (Noor et al., 2010). In addition, one CNV upstream of the gene was found in an individual with ADHD, suggesting that it may play a role in this phenotype as well (Noor et al., 2010). IL1RAPL1, which was initially identified as a cause of NS-ID, and has been shown to cause NS-ID in several individuals, has also been implicated in autism (Carrie et al., 1999; Bhat et al., 2008; Marshall et al., 2008; Piton et al., 2008; Pinto et al., 2010). Similarly, a missense mutation in the NS-ID gene JARID1C was found in an individual with autism (Adegbola et al., 2008). Most recently, a de novo CNV deletion overlapping SYNGAP1, a gene previously implicated in NS-ID, was identified in a female autism proband (Pinto et al., 2010). These genetic links are of much interest, particularly due to the strong phenotypic overlap seen in NS-ID and autism. These common genes will be an important factor in teasing out which biochemical processes are disturbed in different forms of developmental delay, and why a particular mutation in an individual may lead to one condition rather than the other.

\section{Common biological pathways (see Table 2)}

\subsection{The mTOR pathway (see Figure 1)}

The common pathways shared by autism genes are also particularly interesting with respect to ID. While it cannot necessarily be argued that all autism genes will fall into distinct and neat categories, there are certain pathways which are overrepresented among autism-related genes identified so far. One review of the literature suggested that there appear to be two major pathways that known autism genes are a part of: 1 . excitation and inhibition at the synaptic junction and 2. cellular and synaptic growth-i.e. participation in the mTOR pathway (Bourgeron, 2009). This categorization is valid but does not encompass all autism 
genes, and as our knowledge of genes that contribute to the autism phenotype increases, more common pathways may be elucidated.

\begin{tabular}{|c|c|c|c|c|}
\hline Gene Name & ASD or ID* & $\begin{array}{l}\text { Chromosomal } \\
\text { Locus }\end{array}$ & Protein Product & $\begin{array}{c}\text { Potential Pathogenic } \\
\text { Mechanism }\end{array}$ \\
\hline \multicolumn{5}{|c|}{ Common Gene Function: Cell Adhesion } \\
\hline $\mathrm{CDH} 8$ & ASD & $16 \mathrm{q} 22.1$ & Cadherin 8 & $\begin{array}{l}\text { Disruption of neuronal cell } \\
\text { adhesion leading to } \\
\text { aberrant synaptogenesis or } \\
\text { plasticity }\end{array}$ \\
\hline CDH9 & ASD & $5 p 14$ & Cadherin 9 & As above \\
\hline CDH10 & ASD & $5 p 14.2$ & Cadherin 10 & As above \\
\hline CDH15 & ID & $16 q 24.3$ & Cadherin 15 & As above \\
\hline CNTNAP2 & ASD & $7 q 35$ & $\begin{array}{c}\text { Contactin-associated } \\
\text { protein-like } 2\end{array}$ & As above \\
\hline NLGN3 & ASD & Xq13.1 & Neuroligin 3 & $\begin{array}{l}\text { Disruption of neuronal cell } \\
\text { adhesion specifically at the } \\
\text { excitatory synapse leading } \\
\text { to aberrant synaptogenesis } \\
\text { or plasticity }\end{array}$ \\
\hline NLGN4 & ASD/ID & Xp22.33 & Neuroligin 4 & As above \\
\hline NRXN1 & ASD/ID & $2 \mathrm{p} 16.3$ & Neurexin 1 & $\begin{array}{l}\text { Disruption of neuronal cell } \\
\text { adhesion leading to } \\
\text { aberrant synaptogenesis or } \\
\text { plasticity }\end{array}$ \\
\hline PCHD10 & ASD & $4 q 28.3$ & Protocadherin 10 & As above \\
\hline PCDH19 & ID & Xq13.3 & Protocadherin 19 & As above \\
\hline TSPAN7 & ASD/ID & & & As above \\
\hline \multicolumn{5}{|c|}{ Common Gene Function: Receptors at Inhibitory Synapse } \\
\hline $\begin{array}{l}\text { GABA } \\
\text { receptors } \\
(\mathrm{Chr} 4) \\
\end{array}$ & ASD & $4 \mathrm{p} 14$ & $\begin{array}{c}\text { GABA receptors } \alpha 2, \\
\beta 1, \gamma 1 \text { and } \alpha 4\end{array}$ & $\begin{array}{l}\text { Disruption of GABA } \\
\text { receptor activity at the } \\
\text { inhibitory synapse }\end{array}$ \\
\hline $\begin{array}{l}\text { GABA } \\
\text { receptors } \\
(\text { Chr } 15)\end{array}$ & ASD/ID & $15 q 11.2-q 12$ & $\begin{array}{c}\text { GABA receptors a5, } \\
\beta 3, \text { and } \gamma^{3}\end{array}$ & $\begin{array}{l}\text { Disruption of GABA } \\
\text { receptor activity at the } \\
\text { inhibitory synapse }\end{array}$ \\
\hline \multicolumn{5}{|c|}{ Common Gene Function: Regulation and Organization at the Excitatory Synapse } \\
\hline FMR1 & ASD/ID & Xq27.3 & $\begin{array}{c}\text { Fragile } X \text { mental } \\
\text { retardation } 1 \text { protein }\end{array}$ & $\begin{array}{l}\text { Aberrant translational } \\
\text { regulation of important } \\
\text { synaptic genes }\end{array}$ \\
\hline GRIK2 & ASD/ID & 6q16.3-q21 & $\begin{array}{l}\text { Glutamate receptor, } \\
\text { ionotropic, kainate } 2\end{array}$ & $\begin{array}{c}\text { Disruption of Kainate } \\
\text { Receptors at the excitatory } \\
\text { synapse }\end{array}$ \\
\hline
\end{tabular}




\begin{tabular}{|c|c|c|c|c|}
\hline Gene Name & ASD or ID* & $\begin{array}{l}\text { Chromosomal } \\
\text { Locus }\end{array}$ & Protein Product & $\begin{array}{c}\text { Potential Pathogenic } \\
\text { Mechanism }\end{array}$ \\
\hline IL1RAPL1 & ASD/ID & Xp22.1-p21.3 & $\begin{array}{l}\text { Interleukin } 1 \\
\text { receptor accessory } \\
\text { protein-like } 1\end{array}$ & $\begin{array}{l}\text { Disruption of activity and } \\
\text { organization at the } \\
\text { excitatory synapse }\end{array}$ \\
\hline SHANK2 & ASD/ID & $1 q 41$ & $\begin{array}{l}\text { SH3 and multiple } \\
\text { ankyrin repeat } \\
\text { domains } 2\end{array}$ & As Above \\
\hline SHANK3 & ASD/ID & $22 q 13.3$ & $\begin{array}{c}\text { SH3 and multiple } \\
\text { ankyrin repeat } \\
\text { domains } 3\end{array}$ & As Above \\
\hline SYNGAP1 & ASD/ID & $6 \mathrm{p} 21.3$ & $\begin{array}{c}\text { Synaptic Ras } \\
\text { GTPase activating } \\
\text { protein } 1\end{array}$ & $\begin{array}{c}\text { Disruption of NMDA and } \\
\text { AMPA receptors via down } \\
\text { regulation of Ras/ERK } \\
\text { signalling }\end{array}$ \\
\hline \multicolumn{5}{|c|}{ Common Gene Function: Transcriptional Control } \\
\hline ARX & ASD/ID & Xp21.3 & $\begin{array}{c}\text { Aristaless related } \\
\text { homeobox }\end{array}$ & $\begin{array}{c}\text { Disruption of } \\
\text { transcriptional regulation } \\
\text { leading to alterations in } \\
\text { dosage of multiple genes }\end{array}$ \\
\hline AUTS2 & ASD & $7 q 11.2$ & $\begin{array}{c}\text { Autism } \\
\text { susceptibility } \\
\text { gene } 2 \text { protein }\end{array}$ & $\begin{array}{c}\text { Neuronal nuclear } \\
\text { expression; Putative } \\
\text { regulator of transcription } \\
\text { (Kalscheuer et al., 2007) }\end{array}$ \\
\hline JARID1C & ASD/ID & Xp11.22-p11.21 & $\begin{array}{c}\text { Jumonji, AT rich } \\
\text { interactive domain } \\
1 \mathrm{C}\end{array}$ & $\begin{array}{c}\text { Disruption of } \\
\text { transcriptional regulation } \\
\text { leading to alterations in } \\
\text { dosage of multiple genes }\end{array}$ \\
\hline MECP2 & ASD/ID & $\mathrm{Xq} 28$ & $\begin{array}{c}\text { Methyl CpG } \\
\text { binding protein } 2\end{array}$ & As above \\
\hline \multicolumn{5}{|c|}{ Common Gene Function: Down Regulation of the mTOR Signaling Pathway } \\
\hline NF1 & ASD/ID & $17 \mathrm{q} 11.2$ & neurofibromin & $\begin{array}{c}\text { Neuronal cell overgrowth } \\
\text { due to the down } \\
\text { regulation of the mTOR } \\
\text { pathway or down } \\
\text { regulation of Ras/ERK } \\
\text { signaling }\end{array}$ \\
\hline PTEN & ASD & $10 \mathrm{q} 23.3$ & $\begin{array}{c}\text { phosphatidylinositol } \\
\text {-3,4,5-trisphosphate } \\
\text { 3-phosphatase } \\
\text { and dual-specificity } \\
\text { protein } \\
\text { phosphatase }\end{array}$ & $\begin{array}{c}\text { Neuronal cell overgrowth } \\
\text { due to the down regulation } \\
\text { of the mTOR pathway }\end{array}$ \\
\hline TSC1 & ASD/ID & $9 q 34$ & $\begin{array}{c}\text { Tuberous Sclerosis } 1 \\
\text { protein (hamartin) }\end{array}$ & As above \\
\hline
\end{tabular}




\begin{tabular}{|c|c|c|c|c|}
\hline Gene Name & ASD or ID* & $\begin{array}{l}\text { Chromosomal } \\
\text { Locus }\end{array}$ & Protein Product & $\begin{array}{c}\text { Potential Pathogenic } \\
\text { Mechanism }\end{array}$ \\
\hline TSC2 & ASD/ID & $16 \mathrm{p} 13.3$ & $\begin{array}{c}\text { Tuberous Sclerosis } 2 \\
\text { protein (tuberin) }\end{array}$ & As above \\
\hline \multicolumn{5}{|c|}{ Common Gene Function: Varying Functionalities } \\
\hline IQSEC2 & ASD/ID & Xp11.22 & $\begin{array}{c}\text { IQ motif and SEC7 } \\
\text { domain-containing } \\
\text { protein } 2\end{array}$ & $\begin{array}{l}\text { Disruption of the ARF } \\
\text { signaling pathway }\end{array}$ \\
\hline PTCHD1 & ASD/ID & $\mathrm{Xp} 22.11$ & Patched domain 1 & $\begin{array}{l}\text { Potential disruption of the } \\
\text { Hedgehog signaling } \\
\text { pathway }\end{array}$ \\
\hline RELN & ASD/ID & $7 q 22$ & Reelin & $\begin{array}{l}\text { Abnormal neuronal cell } \\
\text { migration and cell-cell } \\
\text { interaction }\end{array}$ \\
\hline SLC6A8 & ASD/ID & $\mathrm{Xq} 28$ & \begin{tabular}{|c} 
Solute carrier family \\
6 member 8
\end{tabular} & Creatine deficiency \\
\hline UPF3B & ASD/ID & Xq25-q26 & $\begin{array}{c}\text { UPF3 regulator of } \\
\text { nonsense transcripts } \\
\text { homolog B }\end{array}$ & $\begin{array}{l}\text { Dysfunction of nonsense } \\
\text { mediated decay and } \\
\text { mRNA surveillance }\end{array}$ \\
\hline
\end{tabular}

*associated with autism spectrum disorder or intellectual disability

Table 2. Genes associated with ASD, ID or both and chromosomal location, along with protein product and function, and the potential route by which the gene results in neurodevelopmental phenotypes.

NF1, TSC1 and TSC2 are genes that, when mutated, may result in disorders neurofibromatosis and tuberous sclerosis respectively- in which there is high incidence of autism- neurofibromatosis and tuberous sclerosis respectively. These genes are negative regulators of the mTOR-raptor complex (mTORC1)-a complex that is important in regulation and cell growth during mitosis and likely plays an active role in synaptogenesis (Bourgeron, 2009). Furthermore, in hippocampus of fmr1 knockout mice, upregulation of mTOR activity has also been reported (Sharma et al., 2010). It can be speculated that when deleterious mutations occur in these genes, the mTOR pathway would become more active due to loss of down regulation. PTEN, another negative regulator of the mTOR pathway has also been implicated in autism. PTEN mutations can lead to PTEN Hamartoma-Tumor Syndrome (PHTS) which includes Cowden Syndrome and Bannayan-Riley-Ruvalcaba Syndrome, but are also present in autism probands without these syndromes (McBride et al., 2010). The mutations found in autism probands appear to be less penetrant than other PTEN mutations (McBride et al., 2010).

With the finding that mTOR genes are involved in autism susceptibility we can propose several possibilities, the first of which is that regulators of the mTORC1 complex may also be good candidates for ID genes, based on overlapping phenotype between autism and ID. However, individuals with neurofibromatosis do not typically present with ID despite having a higher incidence of learning disabilities, ADHD and autism (Hsueh, 2007). Tuberous Sclerosis is associated with learning disabilities, developmental delay including autism and epilepsy in about $85 \%$ of cases (Curatolo et al., 2008). This specificity for autism susceptibility in the mTOR pathway may help us to delineate the complex association between autism and ID genes, and understand how autism specific phenotypes are caused. 


\section{Growth Factors}
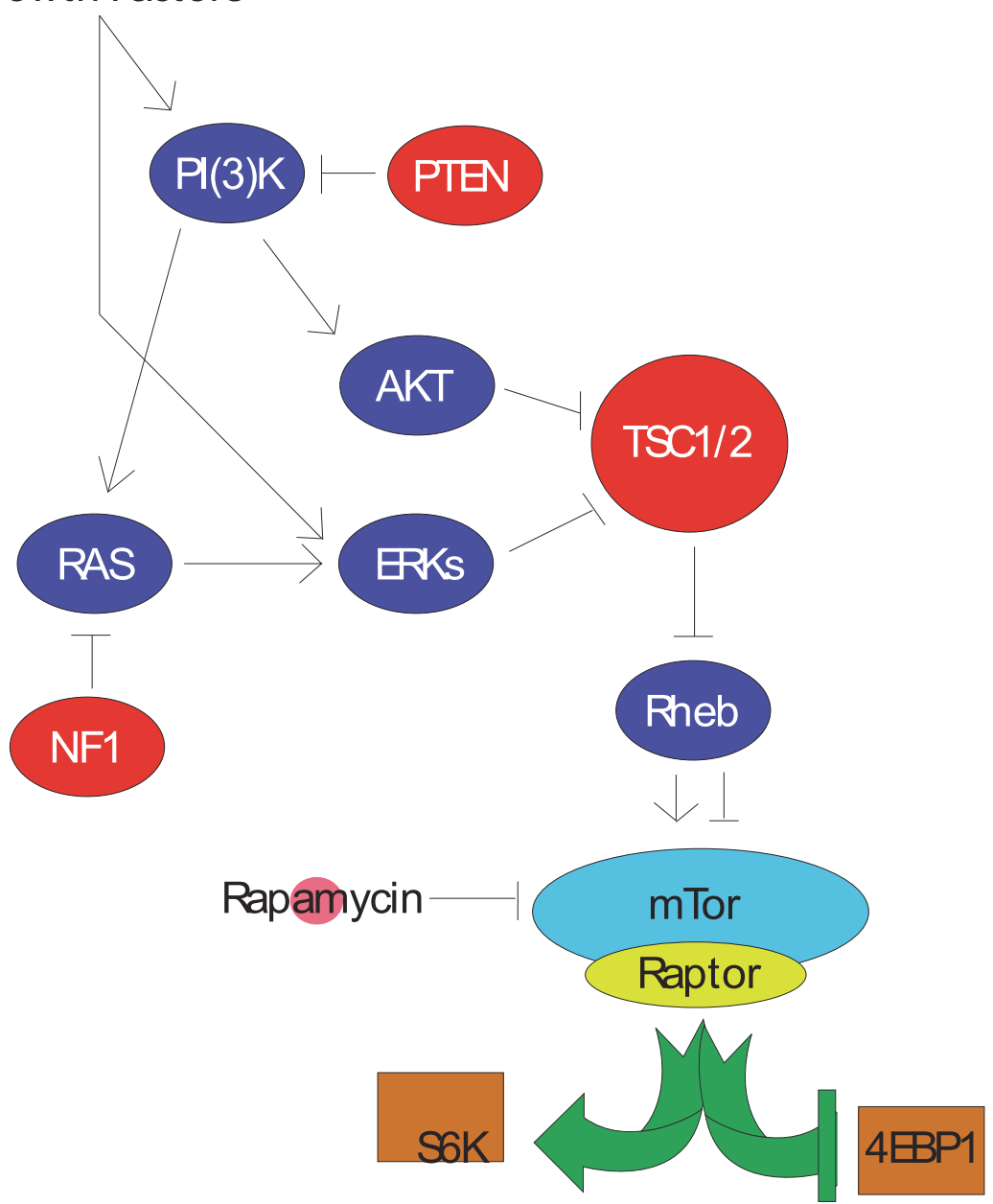

Cell Survival and Growth

Cell Survival Under Stress

The mTOR pathway has been implicated as a potential major contributor to the etiology of autism. The mTOR pathway is negatively regulated by NF1, TSC1/2, and PTEN (and possibly FMRP), all of which are involved in the etiology of autism. mTOR activation results in cell survival and proliferation.

Negative regulation of this pathway prevents overgrowth. Some cancer syndromes are also associated with these genes. mTOR is a target of rapamycin, which inhibits its functioning. This is a potential pharmaceutical candidate for the treatment of syndromes caused by mutations in these genes, as well as autism resulting from mutations in these genes. This figure shows the role of NF1, TSC1/2 and PTEN in the mTOR pathway.

Fig. 1. mTor Pathway in autism and ID 


\subsection{Synaptic proteins and synaptogenesis (see Figures 2 \& 3 )}

Most of the known genes that overlap both autism and ID are present at the synapse and are involved in the excitatory/inhibitory pathway, with an emphasis on excitation. For example, the SHANK family of genes appears to make quite a significant contribution to autism and ID etiologies. Both SHANK2 and SHANK3 encode scaffolding proteins present at the post-synaptic density and in dendrites. They are important for scaffolding in the postsynaptic density - connecting ion channels, neurotransmitter receptors and other membrane proteins to the actin cytoskeleton - and act as a structural framework at this site (Boeckers et al., 2002; Hayashi et al., 2009). They are also likely to play a role in neuronal plasticity (Boeckers et al., 2002; Hayashi et al., 2009).

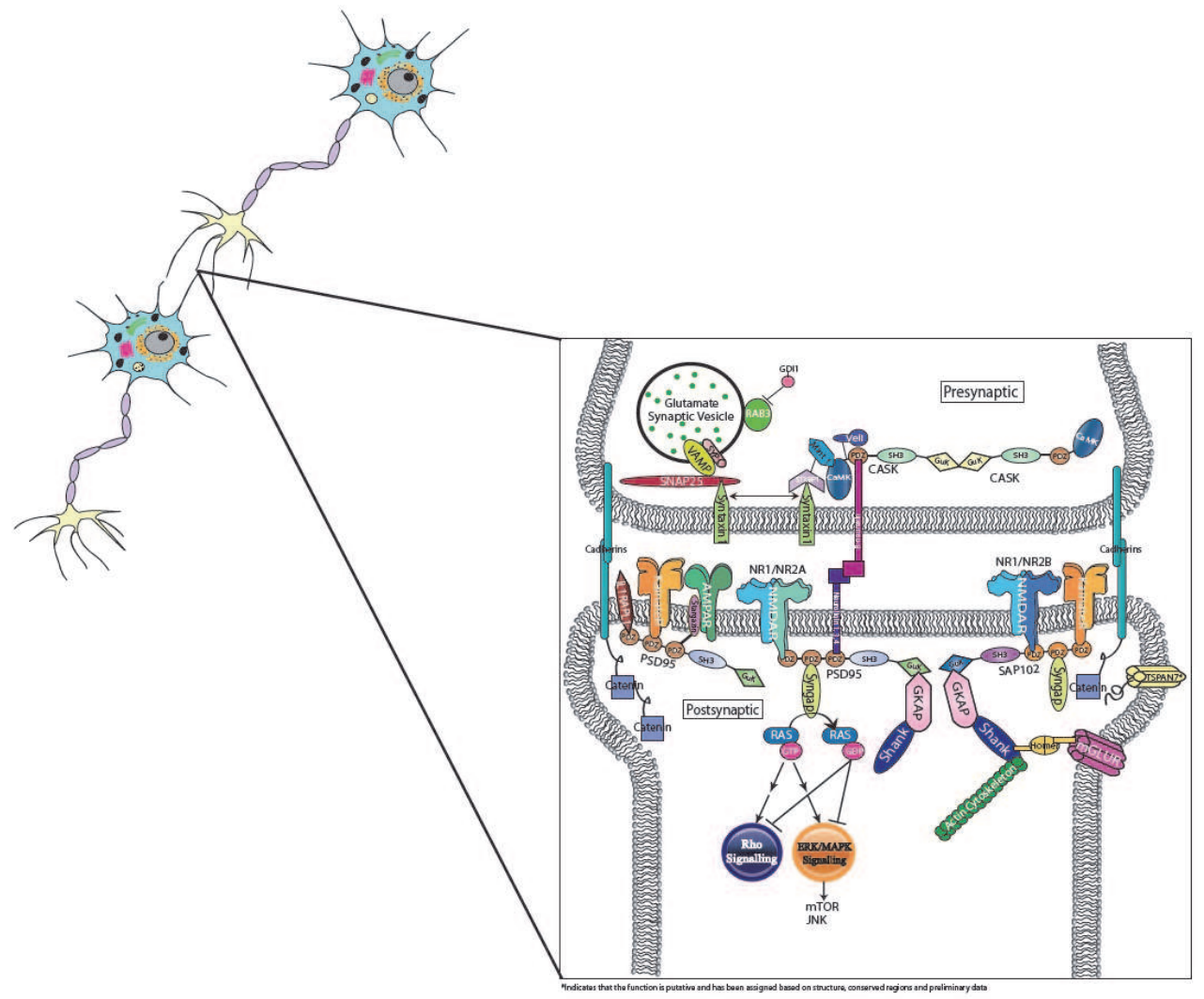

Many autism genes, in particular those that overlap with intellectual disabilities, are present at excitatory synapses. Many of these genes encode protein products which are present in the postsynaptic density (PSD) including SYNGAP1, SHANK2, SHANK3, NLGN4, NLGN3, NRXN1, and IL1RAPL1.

Glutamatergic synapses contain NMDA receptors, AMPA receptors and Kainate receptors. Mutations in additional synaptic genes have been implicated in ID, e.g. CASK and STXBP1. Aberrant function at this synapse has been postulated to be part of both autism and ID etiology.

Fig. 2. Glutamatergic Synapse in autism and ID 


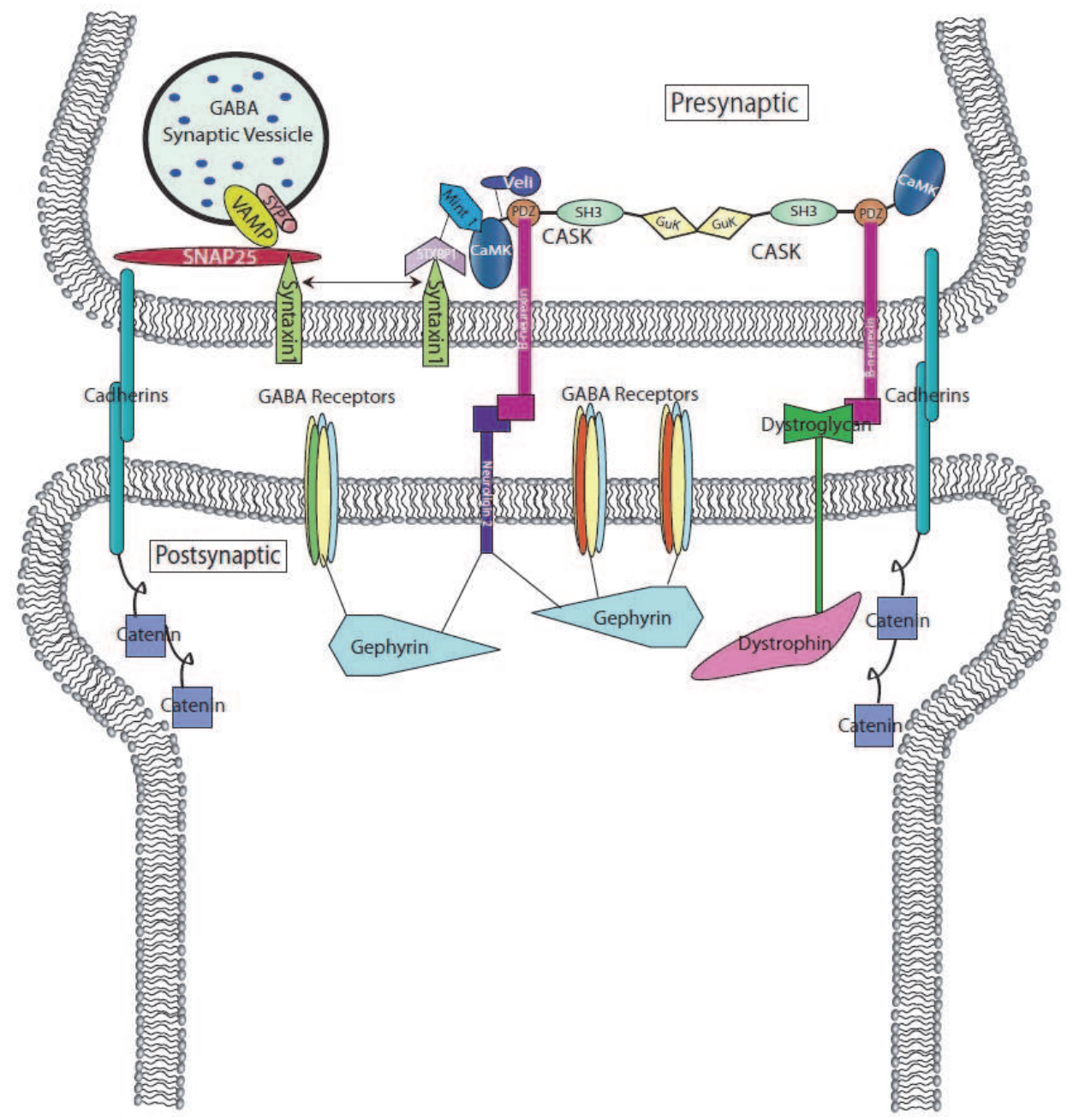

GABA is the major inhibitory neurotransmitter in the human brain. GABA receptor genes have been postulated as candidates for autism etiology. Most GABA receptors cluster in certain chromosomal regions some of which are associated with autism and/or ID, such as 15q11.2-q13 which contains GABRa5, GABR $\beta 3$, and GABR $\gamma 3$, and 4p14 which contains the genes GABR $\alpha 2$, GABR $\beta 1$, GABR $\gamma 1$ and GABRa4. Duplications of the 15q11.2-q13 region are present in 0.5-3\% of autism cases.

Fig. 3. GABAergic Synapse in autism and ID

Another important gene involved in both ID and autism is SYNGAP1 which has been identified as a dominant cause of ID in several individuals with truncating mutations (Hamdan et al, 2009; Hamdan et al, 2011), as well a cause of autism in an individual with a CNV deletion overlapping the gene (Pinto et al. 2010). SYNGAP1 encodes SynGAP - a GTPase activating protein that is part of the NMDA receptor complex (NMDAR), and binds to the NR2B subunit (Kim et al., 2005). NMDARs play a role in glutamate-activated 
excitation of postsynaptic neurons, and have been implicated in memory formation and synaptic plasticity. SynGAP is a negative regulator of NMDAR mediated ERK activation and causes inhibition of the Ras/ERK pathway (Kim et al., 2005). Over-expression of SynGAP has also been shown to down regulate GLuR1, a subunit of AMPA receptors (AMPAR), a class of excitatory ionotropic glutamate receptors which are regulated by the Ras/ERK pathway (Kim et al., 2005; Rumbaugh et al., 2006). Syngap knockout mice implicate SynGAP in the regulation of long term potentiation (LTP) and AMPAR expression (Komiyama et al., 2002). While both ID and autism probands with mutations in this gene were heterozygous for the mutation, individuals with ID have truncating single nucleotide mutations, while the individual with autism had a deleterious $\mathrm{CNV}$, which is an example of how different aberrations within the same gene can have differential effects on phenotypic manifestation, i.e. allelism (Hamdan et al., 2009; Pinto et al., 2010; Hamdan et al., 2011). This has been shown for several other autism/ID genes as well, including IL1RAPL1, JARID1C, and SHANK2 (Adegbola et al., 2008; Piton et al., 2008; Berkel et al., 2010; Pinto et al., 2010).

Other autism-related genes also bind to the NMDAR and are involved in its function. NF1 described earlier as a down regulator of the MTOR pathway also plays a role in the negative regulation of the Ras signaling pathway and is known to bind directly to the NMDAR complex (Hsueh, 2007). This suggests an alternate mechanism for its role in autism. Within the context of Bourgeron's review, this gene is actually affiliated with both "major" autism gene pathways.

In addition IL1RAPL1 also appears to have an impact on NMDAR function. Mutations in IL1RAPL1, a gene with several known mutations in NS-ID and autism, result in the incorrect localization of the MAGUK family protein PSD-95 (DLG4), which is important for organization and function of NMDARs, ion channels and other signaling proteins at the post-synapse (Carrie et al., 1999; Gardoni, 2008; Pavlowsky et al., 2010). The IL1RAPL1 protein has been shown to interact with PSD-95, and knockout of this gene decreased the post-synaptic density (PSD) and the localization of PSD-95 at excitatory synapses. Loss of IL1RAPL1 also results in a decrease of activity in the JNK pathway, which was found to lead to decreased phosphorylation of PSD-95 (Pavlowsky et al., 2010). IL1RAPL1 has also been shown to be important for the formation of excitatory synapses in vivo (Pavlowsky et al., 2010). PSD-95 directly interacts with several known NS-ID associated proteins including: CASK, SynGAP, GLuR6 and neuroligins (Kim \& Sheng, 2004).

GRIK2 is a gene that is mutated in NS-ID (Motazacker et al., 2007) and has been linked by association studies to autism (Jamain et al., 2002; Shuang et al., 2004; Kim et al., 2007) . It encodes a protein called GLuR6, which is a subunit of a kainate receptor (KAR). KARs are ionotropic glutamate receptors which respond to the excitatory neurotransmitter 1glutamate, similar to NMDA or AMPA receptors. They are expressed at a high level in the brain, particularly in the hippocampal mossy fibers, where GLuR6 has been found to modulate LTP in mouse models (Bortolotto et al., 1999; Contractor, Swanson and Heinemann., 2001). GLuR6 knockout mice show decreased LTP in mossy fibers. LTP in the hippocampus has been implicated as a mechanism for memory formation and learning (Bliss \& Collingridge, 1993; Fedulov et al., 2007). While polymorphisms in GRIK2 are likely not responsible for an autism phenotype alone, the association suggests that this locus confers susceptibility to the phenotype and may contribute to the disorder in concert with other genetic aberrations and environmental factors.

Additionally, FMRP, encoded for by FMR1, the fragile X syndrome (FXS) gene, is thought to play a role in neuronal plasticity by acting as a suppressor of local protein translation (as 
reviewed by Jin et al. 2004). It binds mRNA in the nucleus and carries the mRNA to its target destination in the cytoplasm (Bagni \& Greenough, 2005). The transcripts targeted by FMRP include some that are relevant to autism and ID, including PSD-95, DLG1, SHANK1, DLGAP1-4, Grin1, Grin2b, GluR1, and GluR2 (Bassell \& Warren, 2008; Schutt et al., 2009). It also binds other important neuronal transcripts such as itself (FMR1), SEMA3F, CamKII $\alpha$, GABRD, ARC, MAP1B and APP (Bassell \& Warren, 2008). While FXS is an X-linked syndrome of variable phenotype, it is a very common cause of ID, and often is present together with autistic behaviours (de Vries et al., 1998). In addition, the FMR2 gene, which is similar to FMR1 in structure but has a poorly defined function, is also involved in the genetics of ID and autism (Gecz et al., 1996). Mutations in this gene result in intellectual disabilities with or without autistic behaviours.

Some important synaptic genes that are present at inhibitory synaptic junctions appear to be associated with autism and some ID syndromes. GABA is the major inhibitory neurotransmitter in the human brain, and dysfunction of its receptors could result in a decrease of the inhibitory response. A significant amount of research has been done to study the role of GABA and GABA receptors in autism. In particular, GABA receptor subunits residing in clusters on $4 p$ and $15 q$ have been implicated in autism. As indicated earlier, genomic duplications of an imprinted region on the long arm of chromosome 15 (15q11-q13) are present in $0.5-3.0 \%$ of autistic individuals (Hogart et al., 2010). Deletions and uniparental disomy (UPD) in this region are responsible for Angelman syndrome and Prader-Willi syndrome depending on the parent of origin of the mutation, and both of these syndromes present with ID (Dykens et al., 2004), and frequently also with autism (Hogart et al., 2010). This region contains a cluster of three GABA receptor subunit genes: GABRa5, GABR $\beta 3$, and GABR 3 (Dykens et al., 2004). Based on the frequency of this duplication in autism, it is possible that these genes are involved in the autism phenotype, however there are $\sim 10$ genes in the duplicated region, all of which may play a major, minor or no role in the autism phenotype. GABRa2, GABR $\beta 1, G A B R \gamma 1$ and GABRa4 on 4p14 (Ma et al., 2005; Vincent et al., 2006; Kakinuma et al., 2008) have also been implicated in autism. Molecular work specific to some of these GABA receptors supports their role in autism (Ma et al., 2005; Collins et al., 2006; Fatemi et al., 2010). It is also of note that GABA neurotransmission is strongly implicated in fragile $X$ syndrome, and knockout of the fmr1 gene in mice has a hugely disruptive effect on the GABAergic system, and is a potential target for the treatment of symptoms for both Fragile-X syndrome and autism (Hagerman et al., 2005).

Several studies have found significant genetic associations between the chromosome 4 GABA receptor cluster and autism. In addition, specific GABA receptor genes within the $4 p$ cluster have been implicated as likely contributors to autism. GABRa4 was found to be involved in the etiology of autism independently and through interactions with GABR $\beta 1$ (Ma et al., 2005) and both of these genes have been linked to the autism phenotype by association (Collins et al., 2006). Recently, a study by Fatemi et al. indicated that the levels of GABA receptor mRNAs in autism brains are significantly different from controls (Fatemi et al., 2010). The study shows that in the BA9 region of brains acquired from individuals with autism, levels of GABRa4, GABRa5 and GABR $\beta 1$ mRNAs are significantly decreased, while in the cerebella of these brains mRNA for these same genes are increased compared to normal controls after normalization with housekeeping genes (Fatemi et al., 2010). In addition, several small studies and cases have shown that the levels of GABA in peripheral blood and plasma are altered in individuals with autism (Dhossche et al., 2002, Rolf et al., 1993) but these findings are inconsistent, and more thorough and larger scale studies need to be done to determine whether GABA could act as stable biomarker for ASD. 


\subsection{Neuronal cell adhesion}

Neuronal cell adhesion is an interesting common pathway between ID and autism. As previously noted, NLGN4 and NRXN1 are both examples of genes that are mutated in cases of autism and ID. NLGN4 presents us with a particularly interesting genetic link between autism and ID, as it displayed pleiotropy within a single family, with the same mutation causing autism in some individuals, and NS-ID in others. The NLGN4 protein, located on the postsynaptic membrane, interacts with NRXN1 on the presynaptic membrane. Heterozygous mutations in NRXN1 appear to result in autism as well (Autism Genome Project Consortium et al., 2007; Kim et al., 2008). Similar disruptions in NRXN1 have also been documented in schizophrenia (Rujescu et al., 2009), ID, and language delays (Ching et al., 2010). The NLGN4 protein acts as an important element in postsynaptic differentiation, forming complexes with $\beta$-neurexins and PSD-95 (Ichtchenko et al., 1995; Irie et al., 1997; Scheiffele et al., 2000). NLGN4 is linked to glutamatergic postsynaptic proteins and neuroligin/neurexin complexes, which appears to be sufficient for synaptogenesis (Graf et al., 2009). These genes play a major role in both cell adhesion as well as synaptogenesis showing a role for overlap between these pathways.

Additionally, it has been postulated that TSPAN7, an X-linked NS-ID gene, is involved in a complex of $\beta$-integrins, which are involved in cell-cell and cell-matrix interactions (Zemni et al., 2000) and that this gene may cause autism in individuals with deleterious CNVs (Marshall et al., 2008). There are several other neuronal cell adhesion genes that have been implicated in autism, with and without ID, including NLGN3 and CNTNAP2 (Jamain et al., 2003; Alarcon et al., 2008). This suggests that neuronal cell adhesion is a common mechanism by which both autism and ID occur, and may be helpful in elucidating the biological mechanism of these highly related, albeit different, disorders.

In addition to these neuronal cell adhesion genes, several cadherins and protocadherins have been implicated in autism as well. $\mathrm{CDH} 8$ has been found to be disrupted by microdeletions in individuals with learning disabilities and autism, and is not disrupted in over 5000 controls (Pagnamenta et al., 2011). Additionally, a genome-wide association study of individuals with autism identified significant peaks at CDH9 and CDH10 (Wang et al., 2009). PCDH10 has also been suggested as a candidate gene for autism based on a homozygous CNV deletion overlapping the gene in an affected individual (Morrow et al., 2008).

Several similar genes have been implicated in ID as well. PCDH19, a protocadherin, has also been implicated in epilepsy with mental retardation limited to females (EFMR; Dibbens et al., 2008; Hynes et al., 2009). Additionally CDH15 is an autosomal dominant cause of S-ID and NS-ID in several individuals. CDH15 encodes a cadherin that is expressed mainly in brain and skeletal muscle (Bhalla et al., 2008). Mutations of this gene in individuals with ID were found to decrease cell adhesion by greater than $80 \%$ (Bhalla et al., 2008). It is clear from these genetic links that neuronal cell adhesion is a common pathway in both ID and autism. Interestingly, while some of these genes overlap both ID and ASD, some are unique to one condition or the other. It is possible that some of these apparently unique genes may actually be involved in both disorders but no examples have been identified because mutations are so rare. It is also possible that these genes could only cause specific endophenotypes and may be useful for helping us tease out the intricate web of connections between the two disorders. 


\subsection{Transcriptional control}

Disruption of transcriptional control can have far reaching implications in terms of phenotypic manifestation. Genes involved in transcriptional control, when disrupted, may in turn affect the expression of many other genes. For example, $A R X$ is one of the most frequently mutated genes in X-linked NS-ID. It is a homeobox-containing gene that is part of the Aristaless-related gene family. This is a family of transcription factors that are required for various essential events during vertebrate embryogenesis, including CNS development (Meijlink et al. 1999). Based on experimental data and gene structure it has been speculated that $A R X$ regulates transcription by both gene activation and suppression and it is essential for normal development of the CNS (as reviewed by Friocourt et al. 2006). Mutations in this gene have been implicated in many ID syndromes, XLMR and autism/autistic features (Turner et al., 2002; Friocourt et al., 2006).

Another example of a transcription factor involved in both autism and ID is MECP2, the causative gene for Rett syndrome: a regressive syndrome described earlier in this chapter. MECP2 mutations may result in various alternative phenotypic manifestations including MRXS13, LUBS X-linked ID syndrome and NS-ID. While genotype/phenotype data is often ambiguous, some studies have demonstrated a genotype/phenotype correlation in terms of severity, as well as for specific phenotypic measures (Ham et al., 2005; Bebbington et al., 2008). MECP2 encodes the methyl CpG binding protein 2 (MECP2), which is believed to act as a transcriptional modulator that is capable of long-range chromatin re-organization resulting in repression or activation of genes through binding to methylated CpG DNA (As reviewed by Gonzales and LaSalle, 2010).

Additionally, JARIDIC, also known as KMD5C, is another relatively common gene related to X-linked ID with over twenty mutations known in XLMR individuals (Tzschach et al., 2006; Tahiliani et al., 2007). In addition, it has been identified as a causative gene in an individual with autism (Adegbola et al., 2008). JARIDIC is a histone demethylase containing a PHDfinger domain that is characteristic of zinc finger proteins and specifically demethylates diand tri-methylated histone 3 lysine 4 (H3K4me2/me3) residues (Christensen et al., 2007; Tahiliani et al., 2007; Cloos et al., 2008). Trimethylation at this residue is extremely important for transcriptional regulation and chromatin structure. JARID1C is likely involved in repressor element silencing transcription factor (REST)-mediated transcriptional repression. It has been shown to regulate the expression of several REST-mediated genes, as well as regulate the H3K4me2/H3K4me3 levels at their promoters (Tahiliani et al., 2007). Determining which genes these transcriptional regulators control may give insight into the biological pathways involved in disease and the mechanisms by which they occur.

The gene AUTS2 was originally identified through the mapping of a translocation breakpoint on chromosome 7 in a pair of autistic monozygotic twins (Sultana et al., 2002), and subsequently identified in a number of studies of other autism patients with cytogenetic aberrations (Bakkaloglu et al., 2008; Huang et al., 2010). AUTS2 has more recently been identified at the breakpoint for de novo translocations in three unrelated ID individuals (Kalscheuer et al., 2007), as well as at breakpoints of CNVs in individuals with ADHD (Elia et al., 2010) and epilepsy (Mefford et al.. 2010). Although the function of the protein encoded by AUTS2 is unknown, in silico analysis suggest the protein has similarity to known transcription factors (Kalscheuer et al., 2007), and expression studies show that the protein is highly expressed within the nucleus of neurons and neuronal progenitors during development of the cerebral cortex and cerebellum, as well as other regions (Bedogni et al., 2010). As such, it is likely that AUTS2 also functions as a regulator of gene transcription. 


\section{Other genes displaying ID/autism overlap (see Table 2)}

While it is very helpful to look at overlapping autism and ID genes in common pathways, it is not always possible. Autism and ID both have highly variable genetic causes. Some of these causal genes cannot be grouped together in common pathways but are still very important and have been widely implicated in autism and ID. PTCHD1 is an example of such a gene. This gene is estimated to explain $\sim 1 \%$ of cases of autism, as well as several cases of NS-ID (Noor et al., 2010). PTCHD1 is thought to encode a receptor for the hedgehog signaling pathway, however no definitive role for the PTCHD1 protein has yet been established, and as the patched-like domain present in PTCHD1 also has a potential sterolsensing function, there may be sterol transporting pathways implicated (Noor et al., 2010). Mutations at the PTCHD1 locus can occur either within the gene itself or in the region upstream of the gene, which are thought to disrupt PTCHD1 regulation. Additionally, $U P F 3 B$, a component of the nonsense mediated decay surveillance machinery, has been implicated in various ID cases across four families, as well as in several individuals with autism (Tarpey et al., 2007; Addington et al., 2010; Laumonnier et al., 2010). It has also been implicated in childhood onset schizophrenia and ADHD (Addington et al., 2010). IQSEC2, a gene that encodes a GTPase for the ARF family of proteins, is also mutated in several families with ID and varying degrees of ASD and epilepsy (Shoubridge et al., 2010).

\section{Summary}

In this chapter, we have explored the relationship between ASD and ID: two separate but often co-morbid forms of developmental disorder. They are both relatively common in the general population, however the incidence of ASD appears to be on the rise, while ID is relatively stable. Both can be impacted by environmental factors, however ASD appears to have a more complex etiology and may require a combination of genetic, epigenetic and environmental factors to manifest phenotypically. Meanwhile, genes that cause ID tend to be either de novo or passed down in a Mendelian fashion, and are highly penetrant.

While ASD is co-morbid with ID in $40-70 \%$ of cases, ASD can also present with normal intelligence. Certain endophenotypes, such as IQ, head size, presence of dysmorphisms, seizures and MRI abnormalities, may help to predict the effectiveness of early intensive behavioural intervention. Understanding the fundamental differences between "essential" and "complex" autism may be the key to creating personalized behavioural programming that is specific not only for the skills of a particular child, but for the phenotypic specificity conferred by a narrower diagnosis.

It is clear that many of the genes implicated in both ASD and ID cause variable developmental, intellectual and psychiatric phenotypes, with and without additional clinical symptoms. Understanding the molecular mechanisms that result in developmental delays will be useful for potential management and interventions in these disorders. Understanding more about the phenotypes conferred by aberrations in different genes may lead us to develop differential interventions based on these genotypes. Additionally, classification of aberrant molecular pathways may help us to identify biomarkers, which could be used for early diagnosis of these disorders. Individuals with ASD classically respond best to early intensive intervention, thus the earlier we can diagnose ASD, the earlier we can act to help ensure the best outcomes. 


\section{References}

Anonymous (2010) Retraction--Ileal-Lymphoid-Nodular Hyperplasia, Non-Specific Colitis, and Pervasive Developmental Disorder in Children. Lancet 375:445

Abrahams BS and Geschwind DH (2008) Advances in Autism Genetics: On the Threshold of a New Neurobiology. Nat Rev Genet 9:341-355

Addington AM, Gauthier J, Piton A, et al (2010) A Novel Frameshift Mutation in UPF3B Identified in Brothers Affected with Childhood Onset Schizophrenia and Autism Spectrum Disorders. Mol Psychiatry

Adegbola A, Gao H, Sommer S, Browning M (2008) A Novel Mutation in JARID1C/SMCX in a Patient with Autism Spectrum Disorder (ASD). Am J Med Genet A 146A:505511

Alarcon M, Abrahams BS, Stone JL, et al (2008) Linkage, Association, and Gene-Expression Analyses Identify CNTNAP2 as an Autism-Susceptibility Gene. Am J Hum Genet 82:150-159

American Psychiatric Association (2000) Diagnostic and Statistical Manual of Mental Disorders, Fourth Edition, Text Revision. American Psychiatric Association, Washington

Amir RE, Van den Veyver IB, Wan M, Tran CQ, Francke U, Zoghbi HY (1999) Rett Syndrome is Caused by Mutations in X-Linked MECP2, Encoding Methyl-CpGBinding Protein 2. Nat Genet 23:185-188

Arndt TL, Stodgell CJ, Rodier PM (2005) The Teratology of Autism. Int J Dev Neurosci 23:189-199

Ashley-Koch AE, Jaworski J, Ma de Q, et al (2007) Investigation of Potential Gene-Gene Interactions between APOE and RELN Contributing to Autism Risk. Psychiatr Genet 17:221-226

Autism Genome Project Consortium, Szatmari P, Paterson AD, et al (2007) Mapping Autism Risk Loci using Genetic Linkage and Chromosomal Rearrangements. Nat Genet 39:319-328

Bagni C and Greenough WT (2005) From mRNP Trafficking to Spine Dysmorphogenesis: The Roots of Fragile X Syndrome. Nat Rev Neurosci 6:376-387

Bailey DB,Jr, Mesibov GB, Hatton DD, Clark RD, Roberts JE, Mayhew L (1998) Autistic Behavior in Young Boys with Fragile X Syndrome. J Autism Dev Disord 28:499-508

Baird G, Simonoff E, Pickles A, Chandler S, Loucas T, Meldrum D, Charman T (2006) Prevalence of Disorders of the Autism Spectrum in a Population Cohort of Children in South Thames: The Special Needs and Autism Project (SNAP). Lancet 368:210-215

Baird TD and August GJ (1985) Familial Heterogeneity in Infantile Autism. J Autism Dev Disord 15:315-321

Baker JP (2008) Mercury, Vaccines, and Autism: One Controversy, Three Histories. Am J Public Health 98:244-253

Bakkaloglu B, O'Roak BJ, Louvi A, et al (2008) Molecular cytogenetic analysis and resequencing of contactin associated protein-like 2 in autism spectrum disorders. Am J Hum Genet 82:165-173

Bardoni B, Mandel JL, Fisch GS (2000) FMR1 Gene and Fragile X Syndrome. Am J Med Genet 97:153-163 
Baron-Cohen S, Scott FJ, Allison C, Williams J, Bolton P, Matthews FE, Brayne C (2009) Prevalence of Autism-Spectrum Conditions: UK School-Based Population Study. Br J Psychiatry 194:500-509

Bassell GJ and Warren ST (2008) Fragile X Syndrome: Loss of Local mRNA Regulation Alters Synaptic Development and Function. Neuron 60:201-214

Bebbington A, Anderson A, Ravine D, et al (2008) Investigating Genotype-Phenotype Relationships in Rett Syndrome using an International Data Set. Neurology 70:868875

Bedogni F, Hodge RD, Nelson BR, Frederick EA, Shiba N, Daza RA, Hevner RF (2010) Autism susceptibility candidate 2 (Auts2) encodes a nuclear protein expressed in developing brain regions implicated in autism neuropathology. Gene Expr Patterns 10:9-15.

Berkel S, Marshall CR, Weiss B, et al (2010) Mutations in the SHANK2 Synaptic Scaffolding Gene in Autism Spectrum Disorder and Mental Retardation. Nat Genet

Bertrand J, Mars A, Boyle C, Bove F, Yeargin-Allsopp M, Decoufle P (2001) Prevalence of Autism in a United States Population: The Brick Township, New Jersey, Investigation. Pediatrics 108:1155-1161

Beyer KS, Blasi F, Bacchelli E, Klauck SM, Maestrini E, Poustka A, International Molecular Genetic Study of Autism Consortium (IMGSAC) (2002) Mutation Analysis of the Coding Sequence of the MECP2 Gene in Infantile Autism. Hum Genet 111:305-309

Bhalla K, Luo Y, Buchan T, et al (2008) Alterations in CDH15 and KIRREL3 in Patients with Mild to Severe Intellectual Disability. Am J Hum Genet 83:703-713

Bhat SS, Ladd S, Grass F, Spence JE, Brasington CK, Simensen RJ, Schwartz CE, Dupont BR, Stevenson RE, Srivastava AK (2008) Disruption of the IL1RAPL1 Gene Associated with a Pericentromeric Inversion of the X Chromosome in a Patient with Mental Retardation and Autism. Clin Genet 73:94-96

Bliss TV and Collingridge GL (1993) A Synaptic Model of Memory: Long-Term Potentiation in the Hippocampus. Nature 361:31-39

Boddaert N, Zilbovicius M, Philipe A, et al (2009) MRI Findings in 77 Children with NonSyndromic Autistic Disorder. PLoS One 4:e4415

Bodfish JW, Crawford TW, Powell SB, Parker DE, Golden RN, Lewis MH (1995) Compulsions in Adults with Mental Retardation: Prevalence, Phenomenology, and Comorbidity with Stereotypy and Self-Injury. Am J Ment Retard 100:183-192

Bodfish JW, Symons FJ, Parker DE, Lewis MH (2000) Varieties of Repetitive Behavior in Autism: Comparisons to Mental Retardation. J Autism Dev Disord 30:237-243

Boeckers TM, Bockmann J, Kreutz MR, Gundelfinger ED (2002) ProSAP/Shank Proteins - a Family of Higher Order Organizing Molecules of the Postsynaptic Density with an Emerging Role in Human Neurological Disease. J Neurochem 81:903-910

Bolton P, Macdonald H, Pickles A, Rios P, Goode S, Crowson M, Bailey A, Rutter M (1994) A Case-Control Family History Study of Autism. J Child Psychol Psychiatry 35:877900

Bortolotto ZA, Clarke VR, Delany CM, et al (1999) Kainate Receptors are Involved in Synaptic Plasticity. Nature 402:297-301 Bourgeron T (2009) A Synaptic Trek to Autism. Curr Opin Neurobiol 19:231-234

Bradley EA, Thompson A, Bryson SE (2002) Mental Retardation in Teenagers: Prevalence Data from the Niagara Region, Ontario. Can J Psychiatry 47:652-659 
Bromley RL, Mawer G, Clayton-Smith J, Baker GA, Liverpool and Manchester Neurodevelopment Group (2008) Autism Spectrum Disorders Following in Utero Exposure to Antiepileptic Drugs. Neurology 71:1923-1924

Brown WT, Friedman E, Jenkins EC, Brooks J, Wisniewski K, Raguthu S, French JH (1982) Association of Fragile X Syndrome with Autism. Lancet 1:100

Bryson SE, Bradley EA, Thompson A, Wainwright A (2008) Prevalence of Autism among Adolescents with Intellectual Disabilities. Can J Psychiatry 53:449-459

Carrie A, Jun L, Bienvenu T, et al (1999) A New Member of the IL-1 Receptor Family Highly Expressed in Hippocampus and Involved in X-Linked Mental Retardation. Nat Genet 23:25-31

Chakrabarti S and Fombonne E (2001) Pervasive Developmental Disorders in Preschool Children. JAMA 285:3093-3099

Charman T, Jones CR, Pickles A, Simonoff E, Baird G, Happe F (2011) Defining the Cognitive Phenotype of Autism. Brain Res 1380:10-21

Chelly J, Khelfaoui M, Francis F, Cherif B, Bienvenu T (2006) Genetics and Pathophysiology of Mental Retardation. Eur J Hum Genet 14:701-713

Ching MS, Shen Y, Tan WH, et al (2010) Deletions of NRXN1 (Neurexin-1) Predispose to a Wide Spectrum of Developmental Disorders. Am J Med Genet B Neuropsychiatr Genet 153B:937-947

Christensen J, Agger K, Cloos PA, Pasini D, Rose S, Sennels L, Rappsilber J, Hansen KH, Salcini AE, Helin K (2007) RBP2 Belongs to a Family of Demethylases, Specific for Tri-and Dimethylated Lysine 4 on Histone 3. Cell 128:1063-1076

Clarke DF, Roberts W, Daraksan M, Dupuis A, McCabe J, Wood H, Snead OC,3rd, Weiss SK (2005) The Prevalence of Autistic Spectrum Disorder in Children Surveyed in a Tertiary Care Epilepsy Clinic. Epilepsia 46:1970-1977

Cloos PA, Christensen J, Agger K, Helin K (2008) Erasing the Methyl Mark: Histone Demethylases at the Center of Cellular Differentiation and Disease. Genes Dev 22:1115-1140

Collins AL, Ma D, Whitehead PL, et al (2006) Investigation of Autism and GABA Receptor Subunit Genes in Multiple Ethnic Groups. Neurogenetics 7:167-174

Contractor A, Swanson G, Heinemann SF (2001) Kainate Receptors are Involved in Shortand Long-Term Plasticity at Mossy Fiber Synapses in the Hippocampus. Neuron 29:209-216

Cook EH,Jr and Scherer SW (2008) Copy-Number Variations Associated with Neuropsychiatric Conditions. Nature 455:919-923

Curatolo P, Bombardieri R, Jozwiak S (2008) Tuberous Sclerosis. Lancet 372:657-668 de Bildt A, Sytema S, Kraijer D, Minderaa R (2005) Prevalence of Pervasive Developmental Disorders in Children and Adolescents with Mental Retardation. J Child Psychol Psychiatry 46:275-286

de Vries BB, Halley DJ, Oostra BA, Niermeijer MF (1998) The Fragile X Syndrome. J Med Genet 35:579-589

Deb S and Prasad KB (1994) The Prevalence of Autistic Disorder among Children with a Learning Disability. Br J Psychiatry 165:395-399

Dhossche D, Applegate H, Abraham A, Maertens P, Bland L, Bencsath A, Martinez J (2002) Elevated Plasma Gamma-Aminobutyric Acid (GABA) Levels in Autistic Youngsters: Stimulus for a GABA Hypothesis of Autism. Med Sci Monit 8:PR1-6 
Dibbens LM, Tarpey PS, Hynes K, et al (2008) X-Linked Protocadherin 19 Mutations Cause Female-Limited Epilepsy and Cognitive Impairment. Nat Genet 40:776-781

Drews CD, Yeargin-Allsopp M, Decoufle P, Murphy CC (1995) Variation in the Influence of Selected Sociodemographic Risk Factors for Mental Retardation. Am J Public Health 85:329-334

DSM-5 Proposed Revisions Include New Category of Autism Spectrum Disorders (2010) American Psychiatric Association. Release No. 10-09. February 102010

Durand CM, Betancur C, Boeckers TM, et al (2007) Mutations in the Gene Encoding the Synaptic Scaffolding Protein SHANK3 are Associated with Autism Spectrum Disorders. Nat Genet 39:25-27

Durkin M (2002) The Epidemiology of Developmental Disabilities in Low-Income Countries. Ment Retard Dev Disabil Res Rev 8:206-211

Durkin MS, Hasan ZM, Hasan KZ (1998) Prevalence and Correlates of Mental Retardation among Children in Karachi, Pakistan. Am J Epidemiol 147:281-288

Dykens EM, Sutcliffe JS, Levitt P (2004) Autism and 15q11-q13 Disorders: Behavioral, Genetic, and Pathophysiological Issues. Ment Retard Dev Disabil Res Rev 10:284291

Elia J, Gai X, Xie HM, et al. (2010) Rare structural variants found in attention-deficit hyperactivity disorder are preferentially associated with neurodevelopmental genes. Mol Psychiatry 15:637-646

Emerson E (2007) Poverty and People with Intellectual Disabilities. Ment Retard Dev Disabil Res Rev 13:107-113

Fatemi SH, Snow AV, Stary JM, Araghi-Niknam M, Reutiman TJ, Lee S, Brooks AI, Pearce DA (2005) Reelin Signaling is Impaired in Autism. Biol Psychiatry 57:777-787

Fatemi SH, Reutiman TJ, Folsom TD, Rooney RJ, Patel DH, Thuras PD (2010) MRNA and Protein Levels for GABAAalpha4, alpha5, beta1 and GABABR1 Receptors are Altered in Brains from Subjects with Autism. J Autism Dev Disord 40:743-750

Fedulov V, Rex CS, Simmons DA, Palmer L, Gall CM, Lynch G (2007) Evidence that LongTerm Potentiation Occurs within Individual Hippocampal Synapses during Learning. J Neurosci 27:8031-8039

Folstein S and Rutter M (1977) Infantile Autism: A Genetic Study of 21 Twin Pairs. J Child Psychol Psychiatry 18:297-321

Fombonne E (1999) The Epidemiology of Autism: A Review. Psychol Med 29:769-786

Fombonne E (2003) Epidemiological Surveys of Autism and Other Pervasive Developmental Disorders: An Update. J Autism Dev Disord 33:365-382

Fombonne E, Zakarian R, Bennett A, Meng L, McLean-Heywood D (2006) Pervasive Developmental Disorders in Montreal, Quebec, Canada: Prevalence and Links with Immunizations. Pediatrics 118:e139-50

Fombonne E (2009) Epidemiology of Pervasive Developmental Disorders. Pediatr Res 65:591-598

Friocourt G, Poirier K, Rakic S, Parnavelas JG, Chelly J (2006) The Role of ARX in Cortical Development. Eur J Neurosci 23:869-876

Gardoni F (2008) MAGUK Proteins: New Targets for Pharmacological Intervention in the Glutamatergic Synapse. Eur J Pharmacol 585:147-152

Gecz J, Gedeon AK, Sutherland GR, Mulley JC (1996) Identification of the Gene FMR2, Associated with FRAXE Mental Retardation. Nat Genet 13:105-108 
Gillberg C (1986) Autism and Rett Syndrome: Some Notes on Differential Diagnosis. Am J Med Genet Suppl 1:127-131

Gillberg C, Steffenburg S, Schaumann H (1991) Is Autism More Common Now than Ten Years Ago? Br J Psychiatry 158:403-409

Goldman S, Wang C, Salgado MW, Greene PE, Kim M, Rapin I (2009) Motor Stereotypies in Children with Autism and Other Developmental Disorders. Dev Med Child Neurol 51:30-38

Gonzales ML and LaSalle JM (2010) The Role of MeCP2 in Brain Development and Neurodevelopmental Disorders. Curr Psychiatry Rep 12:127-134

Graf ER, Daniels RW, Burgess RW, Schwarz TL, DiAntonio A (2009) Rab3 Dynamically Controls Protein Composition at Active Zones. Neuron 64:663-677

Gurling HM, Bolton PF, Vincent J, Melmer G, Rutter M (1997) Molecular and Cytogenetic Investigations of the Fragile $X$ Region Including the Frax A and Frax E CGG Trinucleotide Repeat Sequences in Families Multiplex for Autism and Related Phenotypes. Hum Hered 47:254-262

Hagberg B, Aicardi J, Dias K, Ramos O (1983) A Progressive Syndrome of Autism, Dementia, Ataxia, and Loss of Purposeful Hand use in Girls: Rett's Syndrome: Report of 35 Cases. Ann Neurol 14:471-479

Hagerman RJ, Ono MY, Hagerman PJ (2005) Recent Advances in Fragile X: A Model for Autism and Neurodegeneration. Curr Opin Psychiatry 18:490-496

Ham AL, Kumar A, Deeter R, Schanen NC (2005) Does Genotype Predict Phenotype in Rett Syndrome? J Child Neurol 20:768-778

Hamdan FF, Gauthier J, Spiegelman D, et al (2009) Mutations in SYNGAP1 in Autosomal Nonsyndromic Mental Retardation. N Engl J Med 360:599-605

Hamdan FF, Gauthier J, Araki Y, et al (2011) Excess of De Novo Deleterious Mutations in Genes Associated with Glutamatergic Systems in Nonsyndromic Intellectual Disability. Am J Hum Genet 88:306-316

Hammer S, Dorrani N, Dragich J, Kudo S, Schanen C (2002) The Phenotypic Consequences

of MECP2 Mutations Extend Beyond Rett Syndrome. Ment Retard Dev Disabil Res Rev 8:9498

Happe F and Ronald A (2008) The 'Fractionable Autism Triad': A Review of Evidence from Behavioural, Genetic, Cognitive and Neural Research. Neuropsychol Rev 18:287304

Hara H (2007) Autism and Epilepsy: A Retrospective Follow-Up Study. Brain Dev 29:486490

Hayashi MK, Tang C, Verpelli C, Narayanan R, Stearns MH, Xu RM, Li H, Sala C, Hayashi Y (2009) The Postsynaptic Density Proteins Homer and Shank Form a Polymeric Network Structure. Cell 137:159-171

Hertz-Picciotto I, Green PG, Delwiche L, Hansen R, Walker C, Pessah IN (2010) Blood Mercury Concentrations in CHARGE Study Children with and without Autism. Environ Health Perspect 118:161-166

Hogart A, Wu D, LaSalle JM, Schanen NC (2010) The Comorbidity of Autism with the Genomic Disorders of Chromosome 15q11.2-q13. Neurobiol Dis 38:181-191

Holt R, Barnby G, Maestrini E, et al (2010) Linkage and Candidate Gene Studies of Autism Spectrum Disorders in European Populations. Eur J Hum Genet 18:1013-1019 
Howlin P, Goode S, Hutton J, Rutter M (2004) Adult Outcome for Children with Autism. J Child Psychol Psychiatry 45:212-229

Hsueh YP (2007) Neurofibromin Signaling and Synapses. J Biomed Sci 14:461-466

Huang XL, Zou YS, Maher TA, Newton S, Milunsky JM (2010) A de novo balanced translocation breakpoint truncating the autism susceptibility candidate 2 (AUTS2) gene in a patient with autism. Am J Med Genet A 152A:2112-2114.

Hughes JR and Melyn M (2005) EEG and Seizures in Autistic Children and Adolescents: Further Findings with Therapeutic Implications. Clin EEG Neurosci 36:15-20

Hurley RS, Losh M, Parlier M, Reznick JS, Piven J (2007) The Broad Autism Phenotype Questionnaire. J Autism Dev Disord 37:1679-1690

Hynes K, Tarpey P, Dibbens LM, et al (2009) Epilepsy and Mental Retardation Limited to Females with PCDH19 Mutations can Present De Novo Or in Single Generation Families. J Med Genet

Ichtchenko K, Hata Y, Nguyen T, Ullrich B, Missler M, Moomaw C, Sudhof TC (1995) Neuroligin 1: A Splice Site-Specific Ligand for Beta-Neurexins. Cell 81:435-443

Irie M, Hata Y, Takeuchi M, Ichtchenko K, Toyoda A, Hirao K, Takai Y, Rosahl TW, Sudhof TC (1997) Binding of Neuroligins to PSD-95. Science 277:1511-1515

Jamain S, Betancur C, Quach H, Philippe A, Fellous M, Giros B, Gillberg C, Leboyer M, Bourgeron T, Paris Autism Research International Sibpair (PARIS) Study (2002) Linkage and Association of the Glutamate Receptor 6 Gene with Autism. Mol Psychiatry 7:302-310

Jamain S, Quach H, Betancur C, et al (2003) Mutations of the X-Linked Genes Encoding Neuroligins NLGN3 and NLGN4 are Associated with Autism. Nat Genet 34:27-29

Jin P, Alisch RS, Warren ST (2004) RNA and microRNAs in Fragile X Mental Retardation. Nat Cell Biol 6:1048-1053

Kakinuma H, Ozaki M, Sato H, Takahashi H (2008) Variation in GABA-A Subunit Gene Copy Number in an Autistic Patient with Mosaic 4 p Duplication (p12p16). Am J Med Genet B Neuropsychiatr Genet 147B:973-975

Kalscheuer VM, FitzPatrick D, Tommerup N, et al (2007) Mutations in Autism Susceptibility Candidate 2 (AUTS2) in Patients with Mental Retardation. Hum Genet 121:501-509

Kanner L (1943) Autistic Disturbances of Affective Contact. Nervous Child 2: 217-250

Katusic SK, Colligan RC, Beard CM, O'Fallon WM, Bergstralh EJ, Jacobsen SJ, Kurland LT (1996) Mental Retardation in a Birth Cohort, 1976-1980, Rochester, Minnesota. Am J Ment Retard 100:335-344

Kaufman L, Ayub M, Vincent JB (2010) The Genetic Basis of Non-Syndromic Intellectual Disability: A Review. J Neurodev Disord 2:182-209

Kim SJ and Cook EH,Jr (2000) Novel De Novo Nonsense Mutation of MECP2 in a Patient with Rett Syndrome. Hum Mutat 15:382-383

Kim E and Sheng M (2004) PDZ Domain Proteins of Synapses. Nat Rev Neurosci 5:771-781

Kim MJ, Dunah AW, Wang YT, Sheng M (2005) Differential Roles of NR2A- and NR2BContaining NMDA Receptors in Ras-ERK Signaling and AMPA Receptor Trafficking. Neuron 46:745-760

Kim SA, Kim JH, Park M, Cho IH, Yoo HJ (2007) Family-Based Association Study between GRIK2 Polymorphisms and Autism Spectrum Disorders in the Korean Trios. Neurosci Res 58:332-335 
Kim HG, Kishikawa S, Higgins AW, et al (2008) Disruption of Neurexin 1 Associated with Autism Spectrum Disorder. Am J Hum Genet 82:199-207

Kleinman JM, Robins DL, Ventola PE, et al (2008) The Modified Checklist for Autism in Toddlers: A Follow-Up Study Investigating the Early Detection of Autism Spectrum Disorders. J Autism Dev Disord 38:827-839

Kogan MD, Blumberg SJ, Schieve LA, Boyle CA, Perrin JM, Ghandour RM, Singh GK, Strickland BB, Trevathan E, van Dyck PC (2009) Prevalence of Parent-Reported Diagnosis of Autism Spectrum Disorder among Children in the US, 2007. Pediatrics 124:1395-1403

Komiyama NH, Watabe AM, Carlisle HJ, et al (2002) SynGAP Regulates ERK/MAPK Signaling, Synaptic Plasticity, and Learning in the Complex with Postsynaptic Density 95 and NMDA Receptor. J Neurosci 22:9721-9732

Laumonnier F, Bonnet-Brilhault F, Gomot M, et al (2004) X-Linked Mental Retardation and Autism are Associated with a Mutation in the NLGN4 Gene, a Member of the Neuroligin Family. Am J Hum Genet 74:552-557

Laumonnier F, Shoubridge C, Antar C, et al (2010) Mutations of the UPF3B Gene, which Encodes a Protein Widely Expressed in Neurons, are Associated with Nonspecific Mental Retardation with Or without Autism. Mol Psychiatry 15:767-776

Leonard H and Wen X (2002) The Epidemiology of Mental Retardation: Challenges and Opportunities in the New Millennium. Ment Retard Dev Disabil Res Rev 8:117-134

Lord C, Rutter M, Le Couteur A (1994) Autism Diagnostic Interview-Revised: A Revised Version of a Diagnostic Interview for Caregivers of Individuals with Possible Pervasive Developmental Disorders. J Autism Dev Disord 24:659-685

Lord C, Risi S, Lambrecht L, Cook EH,Jr, Leventhal BL, DiLavore PC, Pickles A, Rutter M (2000) The Autism Diagnostic Observation Schedule-Generic: A Standard Measure of Social and Communication Deficits Associated with the Spectrum of Autism. J Autism Dev Disord 30:205-223

Ma DQ, Whitehead PL, Menold MM, et al (2005) Identification of Significant Association and Gene-Gene Interaction of GABA Receptor Subunit Genes in Autism. Am J Hum Genet 77:377-388

Marshall CR, Noor A, Vincent JB, et al (2008) Structural Variation of Chromosomes in Autism Spectrum Disorder. Am J Hum Genet 82:477-488

Maulik PK, Mascarenhas MN, Mathers CD, Dua T, Saxena S (2011) Prevalence of Intellectual Disability: A Meta-Analysis of Population-Based Studies. Res Dev Disabil 32:419436

McBride KL, Varga EA, Pastore MT, Prior TW, Manickam K, Atkin JF, Herman GE (2010) Confirmation Study of PTEN Mutations among Individuals with Autism Or Developmental delays/mental Retardation and Macrocephaly. Autism Res 3:137141

McConachie H and Diggle T (2007) Parent Implemented Early Intervention for Young Children with Autism Spectrum Disorder: A Systematic Review. J Eval Clin Pract 13:120-129

McLaren J and Bryson SE (1987) Review of Recent Epidemiological Studies of Mental Retardation: Prevalence, Associated Disorders, and Etiology. Am J Ment Retard 92:243-254 
Mefford HC, Muhle H, Ostertag P, et al (2010) Genome-wide copy number variation in epilepsy: novel susceptibility loci in idiopathic generalized and focal epilepsies. PLoS Genet 6:e1000962

Miles JH, Hadden LL, Takahashi TN, Hillman RE (2000) Head Circumference is an Independent Clinical Finding Associated with Autism. Am J Med Genet 95:339-350

Miles JH and Hillman RE (2000) Value of a Clinical Morphology Examination in Autism. Am J Med Genet 91:245-253

Miles JH, Takahashi TN, Bagby S, Sahota PK, Vaslow DF, Wang CH, Hillman RE, Farmer JE (2005) Essential Versus Complex Autism: Definition of Fundamental Prognostic Subtypes. Am J Med Genet A 135:171-180

Molloy CA, Murray DS, Kinsman A, Castillo H, Mitchell T, Hickey FJ, Patterson B (2009) Differences in the Clinical Presentation of Trisomy 21 with and without Autism. J Intellect Disabil Res 53:143-151

Morrow EM, Yoo SY, Flavell SW, et al (2008) Identifying Autism Loci and Genes by Tracing Recent Shared Ancestry. Science 321:218-223

Motazacker MM, Rost BR, Hucho T, et al (2007) A Defect in the Ionotropic Glutamate Receptor 6 Gene (GRIK2) is Associated with Autosomal Recessive Mental Retardation. Am J Hum Genet 81:792-798

Murch SH, Anthony A, Casson DH, Malik M, Berelowitz M, Dhillon AP, Thomson MA, Valentine A, Davies SE, Walker-Smith JA (2004) Retraction of an Interpretation. Lancet 363:750

Narita M, Oyabu A, Imura Y, Kamada N, Yokoyama T, Tano K, Uchida A, Narita N (2010) Nonexploratory Movement and Behavioral Alterations in a Thalidomide Or Valproic Acid-Induced Autism Model Rat. Neurosci Res 66:2-6

Noor A, Whibley A, Marshall CR, et al (2010) Disruption at the PTCHD1 Locus on Xp22.11 in Autism Spectrum Disorder and Intellectual Disability. Sci Transl Med 2:49ra68

Nordin V and Gillberg C (1996) Autism Spectrum Disorders in Children with Physical Or Mental Disability Or both. I: Clinical and Epidemiological Aspects. Dev Med Child Neurol 38:297-313

Orrico A, Lam C, Galli L, Dotti MT, Hayek G, Tong SF, Poon PM, Zappella M, Federico A, Sorrentino V (2000) MECP2 Mutation in Male Patients with Non-Specific X-Linked Mental Retardation. FEBS Lett 481:285-288

Pagnamenta AT, Khan H, Walker S, et al (2011) Rare Familial 16q21 Microdeletions Under a Linkage Peak Implicate Cadherin 8 (CDH8) in Susceptibility to Autism and Learning Disability. J Med Genet 48:48-54

Pavlowsky A, Gianfelice A, Pallotto M, et al (2010) A Postsynaptic Signaling Pathway that may Account for the Cognitive Defect due to IL1RAPL1 Mutation. Curr Biol 20:103115

Pinto D, Pagnamenta AT, Klei L, et al (2010) Functional Impact of Global Rare Copy Number Variation in Autism Spectrum Disorders. Nature

Piton A, Michaud JL, Peng H, et al (2008) Mutations in the Calcium-Related Gene IL1RAPL1 are Associated with Autism. Hum Mol Genet 17:3965-3974

Piven J, Gayle J, Chase GA, Fink B, Landa R, Wzorek MM, Folstein SE (1990) A Family History Study of Neuropsychiatric Disorders in the Adult Siblings of Autistic Individuals. J Am Acad Child Adolesc Psychiatry 29:177-183 
Rauch A, Hoyer J, Guth S, et al (2006) Diagnostic Yield of various Genetic Approaches in Patients with Unexplained Developmental Delay Or Mental Retardation. Am J Med Genet A 140:2063-2074

Ritvo ER, Spence MA, Freeman BJ, Mason-Brothers A, Mo A, Marazita ML (1985) Evidence for Autosomal Recessive Inheritance in 46 Families with Multiple Incidences of Autism. Am J Psychiatry 142:187-192

Robins DL, Fein D, Barton ML, Green JA (2001) The Modified Checklist for Autism in Toddlers: An Initial Study Investigating the Early Detection of Autism and Pervasive Developmental Disorders. J Autism Dev Disord 31:131-144

Roeleveld N, Zielhuis GA, Gabreels F (1997) The Prevalence of Mental Retardation: A Critical Review of Recent Literature. Dev Med Child Neurol 39:125-132

Rogers SJ, Wehner DE, Hagerman R (2001) The Behavioral Phenotype in Fragile X: Symptoms of Autism in very Young Children with Fragile X Syndrome, Idiopathic Autism, and Other Developmental Disorders. J Dev Behav Pediatr 22:409-417

Rolf LH, Haarmann FY, Grotemeyer KH, Kehrer H (1993) Serotonin and Amino Acid Content in Platelets of Autistic Children. Acta Psychiatr Scand 87:312-316

Ropers HH and Hamel BC (2005) X-Linked Mental Retardation. Nat Rev Genet 6:46-57

Ropers HH (2006) X-Linked Mental Retardation: Many Genes for a Complex Disorder. Curr Opin Genet Dev 16:260-269

Rosenberg RE, Law JK, Yenokyan G, McGready J, Kaufmann WE, Law PA (2009) Characteristics and Concordance of Autism Spectrum Disorders among 277 Twin Pairs. Arch Pediatr Adolesc Med 163:907-914

Rujescu D, Ingason A, Cichon S, et al (2009) Disruption of the Neurexin 1 Gene is Associated with Schizophrenia. Hum Mol Genet 18:988-996

Rumbaugh G, Adams JP, Kim JH, Huganir RL (2006) SynGAP Regulates Synaptic Strength and Mitogen-Activated Protein Kinases in Cultured Neurons. Proc Natl Acad Sci U S A 103:4344-4351

Samaco RC, Hogart A, LaSalle JM (2005) Epigenetic Overlap in Autism-Spectrum Neurodevelopmental Disorders: MECP2 Deficiency Causes Reduced Expression of UBE3A and GABRB3. Hum Mol Genet 14:483-492

Scheiffele P, Fan J, Choih J, Fetter R, Serafini T (2000) Neuroligin Expressed in Nonneuronal Cells Triggers Presynaptic Development in Contacting Axons. Cell 101:657-669

Schifter T, Hoffman JM, Hatten HP,Jr, Hanson MW, Coleman RE, DeLong GR (1994) Neuroimaging in Infantile Autism. J Child Neurol 9:155-161

Schopler E, Reichler RJ, DeVellis RF, Daly K (1980) Toward Objective Classification of Childhood Autism: Childhood Autism Rating Scale (CARS). J Autism Dev Disord 10:91-103

Schutt J, Falley K, Richter D, Kreienkamp HJ, Kindler S (2009) Fragile X Mental Retardation Protein Regulates the Levels of Scaffold Proteins and Glutamate Receptors in Postsynaptic Densities. J Biol Chem 284:25479-25487

Sharma A, Hoeffer CA, Takayasu Y, Miyawaki T, McBride SM, Klann E, Zukin RS (2010) Dysregulation of mTOR Signaling in Fragile X Syndrome. J Neurosci 30:694-702

Shoubridge C, Tarpey PS, Abidi F, et al (2010) Mutations in the Guanine Nucleotide Exchange Factor Gene IQSEC2 Cause Nonsyndromic Intellectual Disability. Nat Genet 42:486-488 
Shuang M, Liu J, Jia MX, Yang JZ, Wu SP, Gong XH, Ling YS, Ruan Y, Yang XL, Zhang D (2004) Family-Based Association Study between Autism and Glutamate Receptor 6 Gene in Chinese Han Trios. Am J Med Genet B Neuropsychiatr Genet 131B:48-50

Skaar DA, Shao Y, Haines JL, et al (2005) Analysis of the RELN Gene as a Genetic Risk Factor for Autism. Mol Psychiatry 10:563-571

Smalley SL, Asarnow RF, Spence MA (1988) Autism and Genetics. A Decade of Research. Arch Gen Psychiatry 45:953-961

South M, Williams BJ, McMahon WM, Owley T, Filipek PA, Shernoff E, Corsello C, Lainhart JE, Landa R, Ozonoff S (2002) Utility of the Gilliam Autism Rating Scale in Research and Clinical Populations. J Autism Dev Disord 32:593-599

Spence SJ and Schneider MT (2009) The Role of Epilepsy and Epileptiform EEGs in Autism Spectrum Disorders. Pediatr Res 65:599-606

Steffenburg S, Gillberg C, Hellgren L, Andersson L, Gillberg IC, Jakobsson G, Bohman M (1989) A Twin Study of Autism in Denmark, Finland, Iceland, Norway and Sweden. J Child Psychol Psychiatry 30:405-416

Steiner CE, Guerreiro MM, Marques-de-Faria AP (2004) Brief Report: Acrocallosal Syndrome and Autism. J Autism Dev Disord 34:723-726

Stevens MC, Fein DA, Dunn M, Allen D, Waterhouse LH, Feinstein C, Rapin I (2000) Subgroups of Children with Autism by Cluster Analysis: A Longitudinal Examination. J Am Acad Child Adolesc Psychiatry 39:346-352

Stromland K, Nordin V, Miller M, Akerstrom B, Gillberg C (1994) Autism in Thalidomide Embryopathy: A Population Study. Dev Med Child Neurol 36:351-356

Stromme P and Diseth TH (2000) Prevalence of Psychiatric Diagnoses in Children with Mental Retardation: Data from a Population-Based Study. Dev Med Child Neurol 42:266-270

Stromme P, Mangelsdorf ME, Scheffer IE, Gecz J (2002) Infantile Spasms, Dystonia, and other X-Linked Phenotypes Caused by Mutations in Aristaless Related Homeobox Gene, ARX. Brain Dev 24:266-268

Sultana R, Yu CE, Yu J, et al (2002) Identification of a novel gene on chromosome 7q11.2 interrupted by a translocation breakpoint in a pair of autistic twins. Genomics 80:129-134.

Symons FJ, Sperry LA, Dropik PL, Bodfish JW (2005) The Early Development of Stereotypy and Self-Injury: A Review of Research Methods. J Intellect Disabil Res 49:144-158

Tahiliani M, Mei P, Fang R, Leonor T, Rutenberg M, Shimizu F, Li J, Rao A, Shi Y (2007) The Histone H3K4 Demethylase SMCX Links REST Target Genes to X-Linked Mental Retardation. Nature 447:601-605

Tarpey PS, Raymond FL, Nguyen LS, et al (2007) Mutations in UPF3B, a Member of the Nonsense-Mediated mRNA Decay Complex, Cause Syndromic and Nonsyndromic Mental Retardation. Nat Genet 39:1127-1133

Toth K, Dawson G, Meltzoff AN, Greenson J, Fein D (2007) Early Social, Imitation, Play, and Language Abilities of Young Non-Autistic Siblings of Children with Autism. J Autism Dev Disord 37:145-157

Tuchman R and Rapin I (2002) Epilepsy in Autism. Lancet Neurol 1:352-358

Turner G, Partington M, Kerr B, Mangelsdorf M, Gecz J (2002) Variable Expression of Mental Retardation, Autism, Seizures, and Dystonic Hand Movements in Two Families with an Identical ARX Gene Mutation. Am J Med Genet 112:405-411 
Tzschach A, Lenzner S, Moser B, et al (2006) Novel JARID1C/SMCX Mutations in Patients with X-Linked Mental Retardation. Hum Mutat 27:389

Viding E and Blakemore SJ (2007) Endophenotype Approach to Developmental Psychopathology: Implications for Autism Research. Behav Genet 37:51-60

Vincent JB, Horike SI, Choufani S, Paterson AD, Roberts W, Szatmari P, Weksberg R, Fernandez B, Scherer SW (2006) An Inversion Inv(4)(p12-p15.3) in Autistic Siblings Implicates the 4p GABA Receptor Gene Cluster. J Med Genet 43:429-434

Volkmar FR, Szatmari P, Sparrow SS (1993) Sex Differences in Pervasive Developmental Disorders. J Autism Dev Disord 23:579-591

Wakefield AJ, Murch SH, Anthony A, et al (1998) Ileal-Lymphoid-Nodular Hyperplasia, Non-Specific Colitis, and Pervasive Developmental Disorder in Children. Lancet 351:637-641

Wang K, Zhang H, Ma D, et al (2009) Common Genetic Variants on 5p14.1 Associate with Autism Spectrum Disorders. Nature 459:528-533

Wassink TH, Piven J, Patil SR (2001) Chromosomal Abnormalities in a Clinic Sample of Individuals with Autistic Disorder. Psychiatr Genet 11:57-63

Wing L and Gould J (1979) Severe Impairments of Social Interaction and Associated Abnormalities in Children: Epidemiology and Classification. J Autism Dev Disord 9:11-29

Witwer AN and Lecavalier L (2007) Autism Screening Tools: An Evaluation of the Social Communication Questionnaire and the Developmental Behaviour ChecklistAutism Screening Algorithm. J Intellect Dev Disabil 32:179-187

Yeargin-Allsopp M, Rice C, Karapurkar T, Doernberg N, Boyle C, Murphy C (2003) Prevalence of Autism in a US Metropolitan Area. JAMA 289:49-55

Zeegers M, Van Der Grond J, Durston S, Nievelstein RJ, Witkamp T, Van Daalen E, Buitelaar J, Engeland HV (2006) Radiological Findings in Autistic and Developmentally Delayed Children. Brain Dev 28:495-499

Zemni R, Bienvenu T, Vinet MC, et al (2000) A New Gene Involved in X-Linked Mental Retardation Identified by Analysis of an X;2 Balanced Translocation. Nat Genet 24:167-170

Zweier C, de Jong EK, Zweier M, et al (2009) CNTNAP2 and NRXN1 are Mutated in Autosomal-Recessive Pitt-Hopkins-Like Mental Retardation and Determine the Level of a Common Synaptic Protein in Drosophila. Am J Hum Genet 85:655-666 


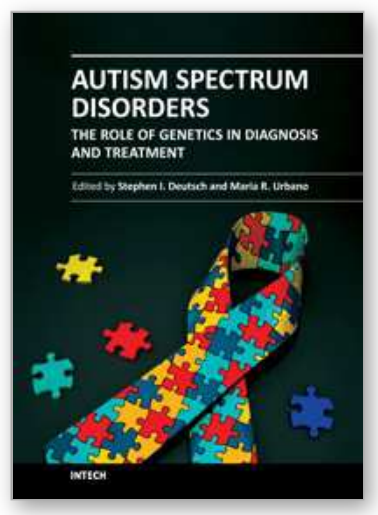

\author{
Autism Spectrum Disorders: The Role of Genetics in Diagnosis and \\ Treatment \\ Edited by Prof. Stephen Deutsch
}

ISBN 978-953-307-495-5

Hard cover, 198 pages

Publisher InTech

Published online 01, August, 2011

Published in print edition August, 2011

Estimated prevalence rates of autism spectrum disorders (ASDs) have increased at an alarming rate over the past decade; current estimates stand as high as 1 in 110 persons in the population with a higher ratio of affected males to females. In addition to their emotional impact on the affected persons and their family members (in fact, the latter are often unrecognized unaffected â€œpatientsâ€ themselves), the economic and social impacts of ASDs on society are staggering. Persons with ASDs will need interdisciplinary approaches to complex treatment and life planning, including, but not limited to, special education, speech and language therapy, vocational skills training and rehabilitation, social skills training and cognitive remediation, in addition to pharmacotherapy. The current book highlights some of the recent research on nosology, etiology, and pathophysiology. Additionally, the book touches on the implications of new research for treatment and genetic counseling. Importantly, because the field is advancing rapidly, no book can be considered the final word or finished product; thus, the availability of open access rapid publication is a mechanism that will help to assure that readers remain current and up-to-date.

\title{
How to reference
}

In order to correctly reference this scholarly work, feel free to copy and paste the following:

Liana Kaufman, Abdul Noor, Muhammad Ayub and John B. Vincent (2011). Common Genetic Etiologies and Biological Pathways Shared Between Autism Spectrum Disorders and Intellectual Disabilities, Autism Spectrum Disorders: The Role of Genetics in Diagnosis and Treatment, Prof. Stephen Deutsch (Ed.), ISBN: 978-953307-495-5, InTech, Available from: http://www.intechopen.com/books/autism-spectrum-disorders-the-role-ofgenetics-in-diagnosis-and-treatment/common-genetic-etiologies-and-biological-pathways-shared-betweenautism-spectrum-disorders-and-intel

\section{INTECH}

open science | open minds

\author{
InTech Europe \\ University Campus STeP Ri \\ Slavka Krautzeka 83/A \\ 51000 Rijeka, Croatia \\ Phone: +385 (51) 770447 \\ Fax: +385 (51) 686166 \\ www.intechopen.com
}

\author{
InTech China \\ Unit 405, Office Block, Hotel Equatorial Shanghai \\ No.65, Yan An Road (West), Shanghai, 200040, China \\ 中国上海市延安西路65号上海国际贵都大饭店办公楼 405 单元 \\ Phone: +86-21-62489820 \\ Fax: +86-21-62489821
}


(C) 2011 The Author(s). Licensee IntechOpen. This chapter is distributed under the terms of the Creative Commons Attribution-NonCommercialShareAlike-3.0 License, which permits use, distribution and reproduction for non-commercial purposes, provided the original is properly cited and derivative works building on this content are distributed under the same license. 